\title{
К ВОПРОСУ О ТРАДИЦИЯХ ИЗГОТОВЛЕНИЯ СФЕРОКОНИЧЕСКИХ СОСУДОВ БОЛГАРСКОГО ГОРОДИЩА (ПО МАТЕРИАЛАМ РАСКОПА 200 (СС) 2014 Г.)
}

\author{
(ㄷ) 2021 г. В.Н. Бахматова, М.В. Сивицкий, А.Г. Ситдиков
}

В данной статье рассматривается проблема состава традиций изготовления сфероконических сосудов в золотоордынском Болгаре. Изложены результаты комплексного изучения серии сфероконусов, включающие типологию сосудов и технологию их изготовления. Зафиксирован неоднородный состав традиций конструирования и формообразования изделий разных типов. Комплекс технологических навыков изготовления сфероконусов соответствует составу навыков гончаров-ремесленников, занимавшихся массовым производством круговой посуды (керамика I общеболгарской группы) в Болгаре. Сосуды раннего типа начали изготовляться в Болгаре в раннезолотоордынское время в мастерских подгорной части города, а сосуды позднего типа - в позднезолотоордынское время в мастерских в районе Голландского озера. Зафиксирована традиция массового использования гончарами при изготовлении сфероконусов обоих типов слабозапесоченной глины, часто с большим количеством различных железистых включений. Это обстоятельство подтверждает специфику сосудов этой категории, связанную с особыми представлениями гончаров об исходном пластичном сырье и местах его добычи.

Ключевые слова: археология Золотой Орды, керамика Болгара, сфероконические сосуды, гончарная технология, источники сырья.

\section{THE ISSUE OF SPHERO-CONICAL VESSEL MANUFACTURING TRADITIONS OF BOLGAR FORTIFIED SETTLEMENT (BASED ON THE MATERIALS OF EXCAVATION 200 (CC) OF 2014)}

\author{
V.N. Bakhmatova, M.V. Sivitsky, A.G. Sitdikov
}

The paper addresses the issue of the composition of sphero-conical vessel manufacturing traditions in the Golden Horde Bolgar. It features the results of a comprehensive study of a series of spherical cones, including the typology of the vessels and the technology of their manufacture. The heterogeneous composition of the traditions of designing and shaping of various types of products has been identified. The set of technological skills of spherical cone manufacture corresponds to the skill set of the artisan potters engaged in the mass production of circular ware (ceramics of the 1st all-Bolgar group) in Bolgar. Vessels of the early type were first manufactured in Bolgar in the early Golden Horde period in the workshops of the piedmont area of the city, and the vessels of the later type - in the Late Golden Horde period in the workshops of Lake Gollandskoe area. The tradition of the common use of both types of slightly oversanded clay, often with a large number of various ferruginous inclusions, by potters during the manufacture of spherical cones has been recorded. This circumstance confirms the specificity of this category of vessels, associated with the special concepts of the potters concerning the original plastic raw materials and their mining locations.

Keywords: archaeology of Golden Horde, Bolgar ceramics, sphero-conical vessels, pottery technology, raw material sources.

Культурный слой Болгарского городища уникален с точки зрения возможностей изучения вещевого и керамического материала. Исследование комплексов артефактов из стратифицированных отложений городища позволяет получать обширную информацию о материальной культуре населения и проследить изменения в хозяйственной жизни населения этого памятника в разные хронологические периоды с VI-VII вв. до начала XV вв.
Культурные напластования, сформировавшиеся в эпоху средневековья на Богарском городище, особенно золотоордынского времени содержат большое разнообразие предметов материальной культуре. Наиболее массовыми в числе находок являются изделий керамики, отличающиеся большим разнообразием форм и техники изготовления. Многие аспекты изучения продукции гончаров средневекового Болгара находят отражение в работах многих 
специалистов, изучающих их производство, технологий изготовления и типологию ассортимента изделий.

Одной из интереснейших категорий керамических находок на городище являются сфероконические сосуды, бытовавшие в средневековье на обширной территории Евразии. Изучение морфологии и некоторых технологических особенностей изготовления сфероконусов позволяет исследователям выявлять центры производства таких сосудов, а наличие продукции разных производственных центров даёт возможность находить торговоэкономические связи между разными городами и государствами.

Свои традиции изготовления сфероконусов существовали и среди гончаров Болгара - крупного торгово-ремесленного и политического центра Поволжья X - начала XV вв. Изучение системы технологических навыков изготовления данной категории посуды позволяет охарактеризовать уровень гончарства населения Болгара и проследить изменения в технологии изготовления сфероконических сосудов в период их бытования на территории этого средневекового города.

История изучения. Одно из первых упоминаний о производстве в Болгаре сфероконических сосудов мы находим в работе О.С. Хованской «Гончарное дело города Болгара»: обломки сфероконических сосудов зафиксированы при исследовании гончарных мастерских золотоордынского времени как в подгорной части Болгарского городища, так и в нагорной части - на северо-западном, юговосточном и юго-западном берегу Голландского озера. Сфероконические сосуды отнесены к ассортименту изделий, производившихся гончарами-ремесленниками в данных мастерских (Хованская, 1954, с. 356, 359-360).

Одну из первых типологических схем классификации сфероконусов из материалов Болгарского городища предложила Т.А. Хлебникова. Сфероконические сосуды Т.А. Хлебникова также как и О.С. Хованская относила к продукции гончаров-ремесленников, занимавшихся изготовлением посуды I общеболгарской группы (Хлебникова, 1988, с. 92-95). Исследователь выделила три основных типа красноглиняных сфероконусов. Тип I представлен сосудами с достаточно широким округлым в верхней части туловом и круты- ми плечиками. Сосуды типа II очень близки к типу I, отличаются только более вытянутыми пропорциями. Сфероконусы с округлым туловом и крутыми плечиками преобладают и связаны с более ранними напластованиями - наиболее характерны для IV раннего слоя (раннезолотоордынское время). Тип III объединяет сосуды с невысоким почти правильной конической формы туловом и плечиками, почти под прямым углом к горловине. Сфероконусы этого типа наиболее характерны для напластований IV позднего слоя (позднезолотоордынское время) и представляют более поздний тип сосудов (Хлебникова, 1988, с. 92-95). Т.А. Хлебникова по аналогии со сфероконусами Биляра экземпляры сероглиняных сосудов соотносила с домонгольским временем (Хлебникова, 1988, с. 97).

Некоторые данные о технологии изготовления сфероконусов из материалов Болгара содержатся в работе И.Н. Васильевой, посвящённой технологии изготовления керамики Болгарского городища. Фрагментарно изучены материалы раскопок Голландского озера. Зафиксированы два способа конструирования: небольшие сосуды изготавливались путем выдавливания двух отдельных частей из комков глины и последующим их соединением, сфероконусы крупных размеров изготавливались спирально-жгутовым налепом по частям с последующим соединением и заглаживанием (Васильева, 1988, с. 128).

Важные сведения о производстве керамической посуды в ходе исследований крупной мастерской Г.Ф. Поляковой в районе Голанского озера (раскоп $70(\mathrm{LXX}))$ - среди продукции также зафиксированы сфероконусы (Полякова, 1980). В 2016 г. были возобновлены археологические работы в районе гончарных мастерских (рис. 1). В результате новых исследований зафиксированы сфероконические сосуды с явным браком производства, указывавшие на их производство в мастерских (Бочаров, 2018, с. 253-269).

Детализованная схема классификация данной категории керамики сосудов предложила А.Р. Нуретдинова, используя материалы работ на Болгарском городище в 2010-2017 гг. (Беляев, Нуретдинова, 2015, с. 301-310). Междисциплинарные исследования неполивной керамики Болгара позволили получить данные о составе сырья, использованного для 
изготовления сфероконусов. Технико-технологический анализ сфероконусов золотоордынского времени из материалов раскопа 172 (CXXII) показал, что для их изготовления применялись формовочные массы на основе запесоченной глины с добавлением выжимки из навоза (Бахматова, Куклина, 2014, с. 242). В рамках проведения работы по поиску источников глинистого сырья для гончарства золотоордынского Болгара была изучена небольшая выборка сфероконусов из раскопов в центральной части городища (раскопы 156 (CLVI), 162 (CLXII)). Локализовать источники сырья, использованного для производста этой серии сфероконических сосудов, в рамках данных работ не удалось (Бахматова, Ситдиков, 2017, с. 255-281). Аналитические исследования сфероконусов показали, что сосуды изготавливались из кварц-полевошпатного сырья с высоким содержанием агрегатов и зёрен кварца (Бахматова, Храмченкова, Ситдиков, 2017, с. 132-133).

Золотоордынский Болгар важен с точки зрения изучения традиций производства сфероконусов, потому что в мастерских на территории города изготавливались красноглиняные сфероконусы разных типов и использовались в хозяйственной деятельности населения города (Хованская, 1954, с. 340-368; Хлебникова, 1988, с. 7-102; Бочаров, 2018, с. 253-269 и др). Существующие исследования сфероконических сосудов Болгарского городища, содержат разнородную информацию о сосудах этой категории: данные о типологии и хронологии, технологии, результаты физико-химической аналитики, гипотезы о функциональном назначении. Главная задача современных научных работ по изучению местных производственных традиций сфероконических сосудов заключается не только в выявлении технологических традиций, но и в установлении связи между типом сосуда и способом его изготовления. Анализ распределения таких «технологических типов» сфероконусов в стратиграфии и топографии города может помочь ответить на вопросы хронологии производства данных сосудов, организации их производства и может быть решить проблему функционального назначения сфероконических сосудов.

При проведении комплексных исследований сосудов данной категории с целью опре- деления традиций производства, источников сырья, функционального назначения и т.д. была отобрана серия сфероконических сосудов из материалов раскопа СС (200) в северо-западной части Болгарского городища. В результате работ на данном раскопе не было зафиксировано производственных объектов. Это обстоятельство позволило составить такую выборку сосудов, которая позволяет охарактеризовать сосуды данной категории в контексте общей материальной культуры населения этого района города. Предварительные результаты этой работы уже были частично опубликованы (Храмченкова и др., 2018; Бахматова и др., 2017, с. 34-38). Последующий анализ полученных данных выявил необходимость подготовки обобщения собранных материалов, что включало в себя изучение традиций производства сфероконусов и определение зависимости между типом сосуда и способом его изготовления.

Методика проведения исследования. Для проведения комплексного изучения сфероконических сосудов выбран междисциплинарный подход с применением, как традиционных методов изучения археологической керамики, так и методов естественнонаучного цикла. Первоначально проведено морфологическое изучение сфероконусов. Для классификации сосудов использована типология, предложенная Т.А. Хлебниковой (Хлебникова, 1988, с. 90-92). Затем, проведен технико-технологический анализ сосудов методами бинокулярной микроскопии и трасологии, разработанный А.А. Бобринским. Для извлечения технологической информации изучались поверхности сосудов и их изломы с целью выявления следов, возникших в результате использования определённых приёмов труда или навыков. Реконструкция всего процесса изготовления сосудов производилась в соответствие со структурой гончарной технологии, включающей три основные стадии - подготовительная (особенности исходного сырья и подготовка формовочных масс), созидательная (конструирование, формообразование, обработка поверхности сосуда) и закрепительная (обжиг сосудов). Для выявления навыков подготовительной стадии изучались изломы сосудов, для характеристики количественных показателей подсчёт осуществлялся на площади излома в 1 см². Для характеристи- 
ки навыков на созидательной стадии анализировались вертикальные и горизонтальные изломы сосудов и их поверхности. Для получения информации о режиме обжига изучались цветовые характеристики сосудов и фрагментов от них после вторичного обжига. Предварительно была проведена подготовка образцов для анализа: небольшие фрагменты от сосудов обожжены в лабораторных условиях в муфельной печи при температуре $900 \mathrm{C}^{\circ}$ для получения равномерной прокалённости черепка в изломе. (Бобринский, 1978; 1999, c. 5-110). Для проведения анализа использован бинокулярный стереоскопический микроскоп МСП-1 с увеличением от 10 до 80 крат. Уточнение состава и микро-фотофиксация производилась с использованием микроскопа Zeiss Discovery V20 (НИЛ междисциплинарных инновационных и научно-практических исследований Института международных отношений КФУ, г. Казань). Для выяснения особенностей химического состава, связанного с сырьевой базой гончарства Болгара, для образцов от всех сосудов был проведён эмиссионный спектральный анализ (ЭСА). Анализ проведён к.ф.-м.н. Р.Х. Храмченковой на базе Института археологии им. А.Х. Халикова АН РТ. Проведённый анализ соответствует количественному анализу III категории точности (Храмченкова, 2014, с. 176-204).

Характеристика источника и типология сосудов. Раскоп 200 (СС) общей площадью 1459 м² был заложен в северо-западной части городища (рис. 1). В результате проведения раскопок был выявлен культурный слой мощностью 60-100 см вне объектов. В стратиграфии зафиксированы следующие культурно-хронологические горизонты: I хронологически соотносится с периодом XIX - XXI вв.; II - связан с функционированием здесь русской деревни в XVIII - начале XIX вв.; IV - отложился в золотоордынский период истории города Болгар, в котором выделено два горизонта - поздний (с 30-х гг. XIV в. до 1431 г. - даты разгрома города войсками Фёдора Пёстрого) и ранний (с 1236 г. до 30-х гг. XIV вв.); V - соотносится со второй половиной домонгольского периода (вторая половина XI - первая треть XIII вв.). Все выделенные горизонты соответствуют общепринятой стратиграфической шкале Болгара (Хлебникова, 1987, с. 34-89). Результаты исследова- ний на данном раскопе подтвердили сформировавшееся среди исследователей мнение, что наиболее освоенной в хозяйственном отношении эта территория была в золотоордынское время - здесь располагался ремесленно-жилой район города Болгар (Хлебникова, 1987, с. 34-89; Валиев, Бадеев, 2018, с. 137-141; Бадеев, 2018, с. 81-86).

По итогам работ на раскопе 200 (СС) был собран комплекс керамики общей численностью 24256 фрагментов. Сфероконические сосуды составляют всего 0,28\% (рис. 2: 1). Примерно такое количество сосудов этой категории зафиксировано среди материалов раскопов на этом участке (Баранов, 2011. Ч III, с. 64; 2016. Ч. II, с. 91-128; 2018, с. 262; Баранов, Губайдуллин, 2012а, с. 5-28; 2012б, c. 5-26; Валиев, 2014, с. 120-131; Ситдиков, 2017, с. 91-104; 2018, приложение 2) (рис. 1; 2: 1). Сфероконусы практически не зафиксированы в горизонтах, сформировавшихся в домонгольское и раннезолотоордынское время. Основная часть происходит из отложений позднезолотоордынского периода - до $72 \%$ от общего количества сфероконусов из этого раскопа (рис. 2: 2).

Сильная фрагментированность сфероконических сосудов исследуемой выборки не позволяет использовать детальные схемы для их классификации. Наиболее удобной в данном случае является типология красноглиняных сфероконусов Болгара, предложенная T.А. Хлебниковой. Рассмотрим подробнее выборку сосудов в соответствие с их местонахождением (табл. 1). Часть сосудов (11 экз.) обнаружена в слоях I-II. Изготовление этих сосудов не связано с периодом формирования данных напластований. Сфероконусы попали в эти отложения посредством переработки ранних напластований в процессе хозяйственной деятельности в более позднее время. Выборка сфероконусов из данных отложений интересна типологическим разнообразием.

Из заполнения хозяйственных построек XIX и XX вв. - слой I (сооружения 5, 4, 7, 16, 79, 95) происходят 7 сфероконических сосудов. Два из них соотносится с типами I-II. Из заполнения полуземлянок этого периода выбрано два сфероконуса серого цвета. Один из них представляет собой стенку от сосуда светло-серого цвета с ангобированной внутренней поверхностью, черепок очень 


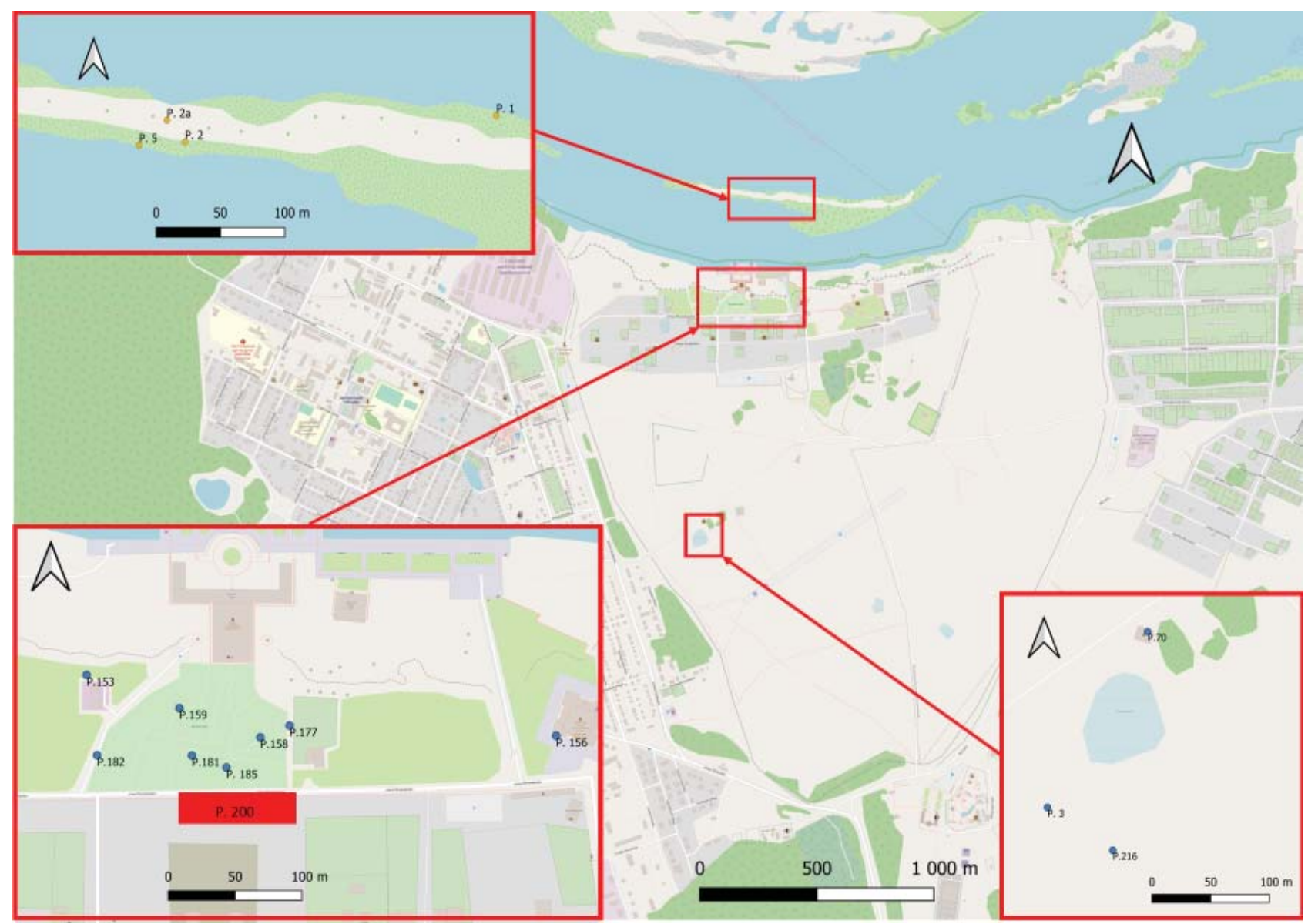

Рис. 1. Карта расположения раскопов на Болгарском городище: Р. 1 - раскоп А.П. Смирнова, 3. А. Акчуриной в 1952 г.; Р. 2 - раскоп Б.Б. Жиромского в 1951 г.; Р. 2а - раскоп А.П. Смирнова, В.В. Седова в 1950 г.; Р. 3 - раскоп О.С. Хованской в 1948 г.; Р. 5 - раскоп О.С. Хованской, В.А. Тихомирновой в 1951 г.;

Р. 70 - раскоп Г.Ф. Поляковой в 1980 г.; Р. 153 - раскоп В.С. Баранова в 2011 г.; Р. 156 - ; Р. 158 и Р. 159 - раскопы В.С. Баранова, А.М. Губайдуллина в 2011 г.; Р. 177, Р. 182 - раскопы В.С. Баранова в 2012 г.; Р. 181 - раскоп Р.Р. Валиева в 2012 г.; Р. 185 - раскоп А.Г. Ситдикова в 2013 г.; Р. 200 - раскоп М.В. Сивицкого в 2014 г.; Р. 216 - раскоп А. Г. Ситдикова в 2016 г.

Fig. 1. Layout of the excavations at Bolgar fortiied settlement: Ex. 1 - excavation by A.P. Smirnov, Z.A. Akchurina in 1952; Ex. 2 - excavation by B.B. Zhiromsky in 1951; Ex. 2a - excavation by A.P. Smirnov, V.V. Sedov in 1950;

Ex. 3 - excavation by O.S. Khovanskaya in 1948; Ex. 5 - excavation by O.S. Khovanskaya, V.A. Tikhomirnova in 1951; Ex. 70 - excavation by G.F. Polyakova in 1980; Ex. 153 - excavation by V.S. Baranov in 2011; Ex. 156, Ex. 158 and Ex. 159 - excavations by V.S. Baranov, A.M. Gubaidullin in 2011; Ex. 177, Ex. 182 - excavations by V.S. Baranov in 2012; Ex. 181 - excavation by R.R. Valiev in 2012; Ex. 185 - excavation by A.G. Sitdikov in 2013; Ex. 200 - excavation by M.V. Sivitsky in 2014; Ex. 216 - excavation by A.G. Sitdikov in 2016.

плотный (рис. 3: 2). Другой - придонная часть сосуда темно-серого цвета с округлым яйцевидным, слегка уплощенным дном, черепок не такой плотный как у предыдущего сосуда (рис. 3: 1). Такую форму придонной части А.Х. Халиков описывал для сфероконических сосудов Билярского городища - тип IV. Cocyды этого типа характерны для производства городов Средней Азии (Халиков, 1986, с. 81). Остальные сосуды были отнесены к типу III. Из материалов слоя II выбрано 4 сфероконических сосуда: придонные части сосудов типа I-II (рис. 4: 3); придонная часть сфероконуса типа III; фрагмент плеча сосуда неопределённого типа из заполнения постройки (табл. 1).
Наибольший интерес представляют сфероконические сосуды, происходящие из построек и напластований, соотносящихся с IV поздним слоем Болгара, из которого было отобрано 15 фрагментов (30-е гг. XIV в. - 1431 г.). Из слоя вне объектов выбраны фрагменты верхних и придонных частей красноглиняных сфероконусов типов I-II (рис. 4: 1-2), III (рис. 5: 1, 3). Серия сосудов выбрана из материалов заполнения большой землянки 30-40-х гг. XIV в. (сооружение 67). Преобладают сосуды типа III (рис. 5: 1, 3-4). К заполнению хозяйственной ямы (сооружение 81) и ямы с человеческими останками на дне (сооружение 17) относятся фрагменты стенок сферокониче- 
1

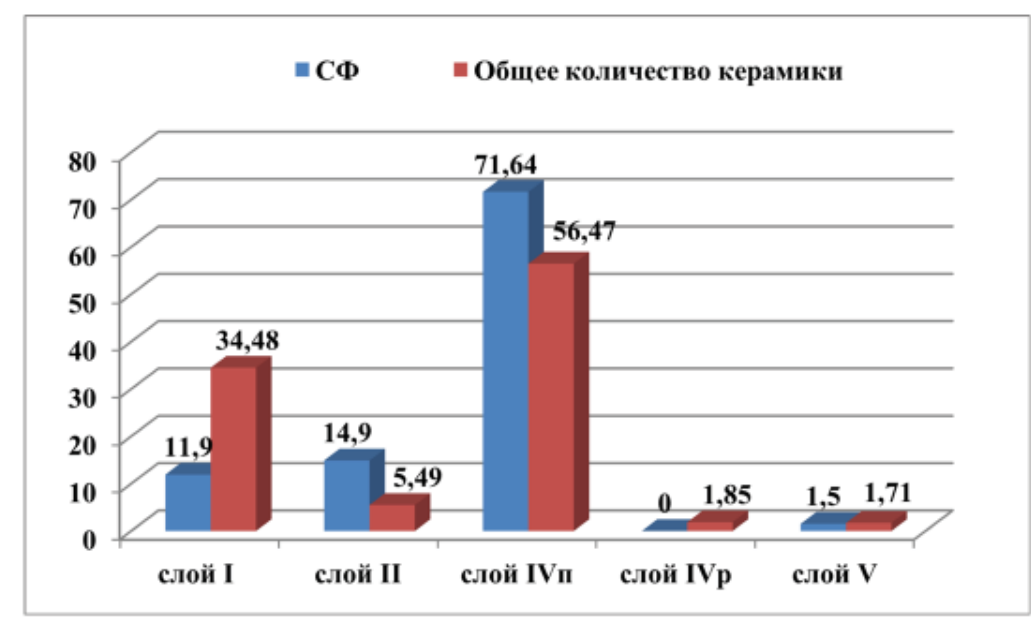

2

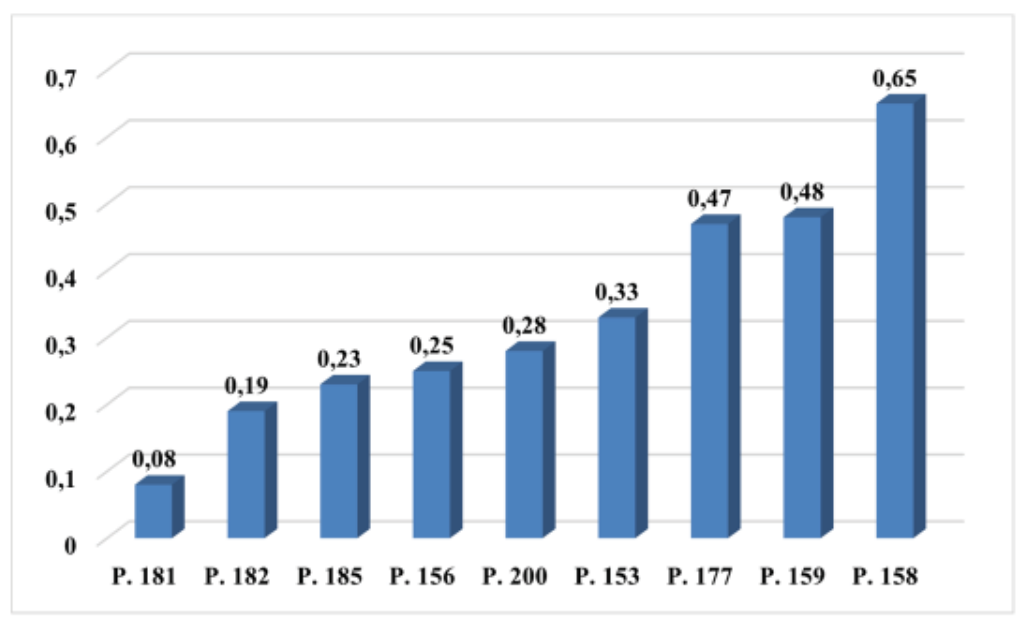

Рис. 2: 1 - распределение сфероконических сосудов и неполивной керамики в хронологических горизонтах Болгарского городища на раскопе СС (в \%); 2 - содержание сфероконических сосудов в раскопах северозападной части Болгарского городища.

Fig. 2: 1 - distribution of sphero-conical vessels and non-glazed ceramics in the chronological horizons of Bolgar fortified settlement at excavation CC (in \%); 2 - content of sphero-conical vessels in the excavations of the northwestern area of Bolgar fortified settlement.

ских сосудов, тип которых определить невозможно (табл. 1).

Результаты технологического изучения сосудов. Рассмотрим особенности технологии изготовления сфероконусов разных типов в соответствие со структурой гончарной технологии.

Стадия I - подготовительная. Ступени 1-3 - отбор, добыча и подготовка исходного пластичного сырья. В качестве исходного пластичного сырья (ИПС) для изготовления всех сосудов этой серии использованы природные глины или их смеси. В качестве естественных примесей в глинах зафиксированы: пылевидный песок (зерна размером до 0, 1 мм), включения зёрен песка различной морфологии и цвета размером от 0,15 до 0,8 мм, единичные включения окатаной гальки размером до 3-5 мм. В большинстве сосудов зафиксированы включения бурых железняков, представляющих собой окатаные или неокатаные с бугристой поверхностью шарики темно-серого с металлическим блеском или буро-коричневого цвета размером до 1-2 реже 3 мм (рис. 6: 1, 3). Часто встречаются аморфные железистые включения темно-серого или буро-коричневого цветов (ярко-малиновые после вторичного обжига) размером от 0,5-3 мм (рис. 6: 4). В зависимости от количества естественных примесей пластичное 
Таблица 1. Перечень сфероконических сосудов раскопа СС

Болгарского городища, использованных для анализа

Table 1. List of sphero-conical vessels from excavation $\mathrm{CC} \mathrm{o}$

f Bolgar fortified settlement used for analysis

\begin{tabular}{|c|c|c|c|c|c|}
\hline $\begin{array}{l}\text { № } \\
\text { ПП }\end{array}$ & ШИФР & ТИП & ОПИСАНИЕ & СЛОЙ & МЕСТОНАХОЖДЕНИЕ \\
\hline 1 & СФ-6 & $\mathrm{IV}^{1}$ & Придонная часть сероглиняного сфероконуса & I & $\begin{array}{l}\text { Уч. Е/19, сооружение } 16, \\
\text { гл. - } 120 \text { см. }\end{array}$ \\
\hline 2 & СФ-7 & III (?) & $\begin{array}{c}\text { Фрагмент придонной части красноглиняного } \\
\text { сфероконуса }\end{array}$ & I & $\begin{array}{c}\text { Уч. Е-Ж-3/ 32, сооружение } \\
\text { 95, гл. }-80 \text { см. }\end{array}$ \\
\hline 3 & СФ-2 & III & $\begin{array}{c}\text { Фрагмент придонной части красноглиняного } \\
\text { сфероконуса. }\end{array}$ & I & $\begin{array}{c}\text { Уч. А-Б/ 13-14, сооружение } \\
\text { 5, гл. }-270 \text { см. }\end{array}$ \\
\hline 4 & СФ-9 & I-II & $\begin{array}{l}\text { Фрагмент плеча красноглиняного } \\
\text { сфероконуса. }\end{array}$ & I & $\begin{array}{c}\text { Уч. А-Б/ 13-14, сооружение } \\
\text { 5, гл. - } 290 \text { см. } \\
\end{array}$ \\
\hline 5 & СФ-13 & III (?) & $\begin{array}{c}\text { Фрагмент верхней части ошлакованного } \\
\text { сфероконуса }\end{array}$ & I & $\begin{array}{c}\text { Уч. Е-Ж/ 11-12, сооружение } \\
\text { 4, гл. }-60 \text { см. } \\
\end{array}$ \\
\hline 6 & СФ-19 & Импорт? & $\begin{array}{c}\text { Фрагмент стенки сероглиняного сфероконуса } \\
\text { с ангобом на внутренней поверхности }\end{array}$ & I & $\begin{array}{c}\text { Уч. Г/ 14, сооружение } 7, \text { гл. } \\
-60 \text { см. }\end{array}$ \\
\hline 7 & СФ-22 & I-II & $\begin{array}{c}\text { Фрагмент придонной части красноглиняного } \\
\text { сосуда }\end{array}$ & I & $\begin{array}{c}\text { Уч. Г/ 9, сооружение } 79, \text { гл. } \\
\text { - } 160 \text { см. }\end{array}$ \\
\hline 8 & СФ-26 & ? & $\begin{array}{l}\text { Фрагмент плеча красноглиняного } \\
\text { сфероконуса. }\end{array}$ & II & $\begin{array}{c}\text { Уч. Г/1-2, сооружение 2, гл. } \\
-160 \text { см. } \\
\end{array}$ \\
\hline 9 & СФ-17 & I-II & $\begin{array}{c}\text { Придонная часть красноглиняного } \\
\text { сфероконуса }\end{array}$ & II & Уч. Д/3, гл. -20 см. \\
\hline 10 & СФ-18 & III (?) & $\begin{array}{c}\text { Фрагмент придонной части красноглиняного } \\
\text { сфероконуса }\end{array}$ & II & Уч. Д/3, гл. - 20 см. \\
\hline 11 & СФ-25 & I-II & $\begin{array}{c}\begin{array}{c}\text { Фрагмент придонной части красноглиняного } \\
\text { сфероконуса }\end{array} \\
\end{array}$ & II & Уч. Ж/31, гл. - 40 см. \\
\hline 12 & СФ-5 & I-II & $\begin{array}{c}\text { Фрагмент горла красноглиняного } \\
\text { сфероконуса }\end{array}$ & IV п & Уч. В/ 41, гл. - 80 см. \\
\hline 13 & СФ-8 & I-II (?) & $\begin{array}{c}\text { Фрагмент стенки красноглиняного } \\
\text { сфероконуса } \\
\end{array}$ & IV п & Уч. В/ 37, гл. - 60 см. \\
\hline 14 & СФ-12 & I-II & $\begin{array}{c}\text { Верхняя часть (горлышко + плечо) } \\
\text { красноглиняного сфероконуса }\end{array}$ & IV п & Уч. Б/ 41, гл. -80 см. \\
\hline 15 & СФ-14 & I-II & $\begin{array}{c}\text { Фрагмент верхней части (горлышко + плечо) } \\
\text { красноглиняного сфероконуса }\end{array}$ & IV п & Уч. Г/ 18, гл. - 60 см. \\
\hline 16 & СФ-4 & III & $\begin{array}{c}\text { Фрагмент плеча красноглиняного } \\
\text { сфероконуса }\end{array}$ & IV п & Уч. А/ 17, гл. -80 см. \\
\hline 17 & СФ-11 & III & $\begin{array}{c}\text { Фрагмент верхней части (горлышко + плечо) } \\
\text { красноглиняного сфероконуса }\end{array}$ & IV п & Уч. Е-Ж/ 5-6, гл. - 60 см. \\
\hline 18 & СФ-15 & III & $\begin{array}{c}\text { Фрагмент придонной части красноглиняного } \\
\text { сфероконуса }\end{array}$ & I & Сборы с поверхности \\
\hline 19 & СФ-21 & III & $\begin{array}{c}\text { Фрагмент плеча красноглиняного } \\
\text { сфероконуса }\end{array}$ & IV п & Уч. В/ 5, гл. - 180 см. \\
\hline 20 & СФ-1 & III & $\begin{array}{c}\text { Фрагмент придонной части красноглиняного } \\
\text { сфероконуса }\end{array}$ & IV п & $\begin{array}{l}\text { Уч. Д/ 29-30, сооружение } \\
67, \text { гл. }-140 \text { см. } \\
\end{array}$ \\
\hline 21 & СФ-3 & III & $\begin{array}{c}\begin{array}{c}\text { Фрагмент верхней части (горлышко + плечо) } \\
\text { красноглиняного сфероконуса }\end{array} \\
\end{array}$ & IV п & $\begin{array}{l}\text { Уч. Д/ 29-30, сооружение } \\
\text { 67, гл. - } 100 \text { см. }\end{array}$ \\
\hline 22 & СФ-10 & III & $\begin{array}{c}\text { Фрагмент верхней части (горлышко + плечо) } \\
\text { красноглиняного сфероконуса }\end{array}$ & IV п & $\begin{array}{l}\text { Уч. Д/ 29-30, сооружение } \\
67, \text { гл. }-240 \text { см. }\end{array}$ \\
\hline 23 & СФ-16 & III & $\begin{array}{c}\text { Придонная часть красноглиняного } \\
\text { сфероконуса }\end{array}$ & IV п & $\begin{array}{l}\text { Уч. Д/ 29-30, сооружение } \\
\text { 67, гл. - } 140 \text { см. }\end{array}$ \\
\hline 24 & СФ-20 & I-II & $\begin{array}{c}\text { Фрагмент плеча красноглиняного } \\
\text { сфероконуса }\end{array}$ & IV п & $\begin{array}{l}\text { Уч. Е/ 29, сооружение } 67, \\
\text { гл. }-220 \text { см. }\end{array}$ \\
\hline 25 & СФ-23 & $?$ & $\begin{array}{c}\text { Фрагмент стенки красноглиняного } \\
\text { сфероконуса }\end{array}$ & IV п & $\begin{array}{c}\text { Уч. Е-Н/ 5-6, сооружение } \\
17, \text { гл. }-140 \text { см. } \\
\end{array}$ \\
\hline 26 & СФ-24 & $?$ & $\begin{array}{c}\begin{array}{c}\text { Фрагмент придонной части красноглиняного } \\
\text { сфероконуса }\end{array} \\
\end{array}$ & IV п & $\begin{array}{c}\text { Уч. Б-В/ 3-6, сооружение } \\
81, \text { гл. }-240 \text { см. }\end{array}$ \\
\hline
\end{tabular}

${ }^{1}$ По типологии А.Х. Халикова для сфероконусов Билярского городища. 
1

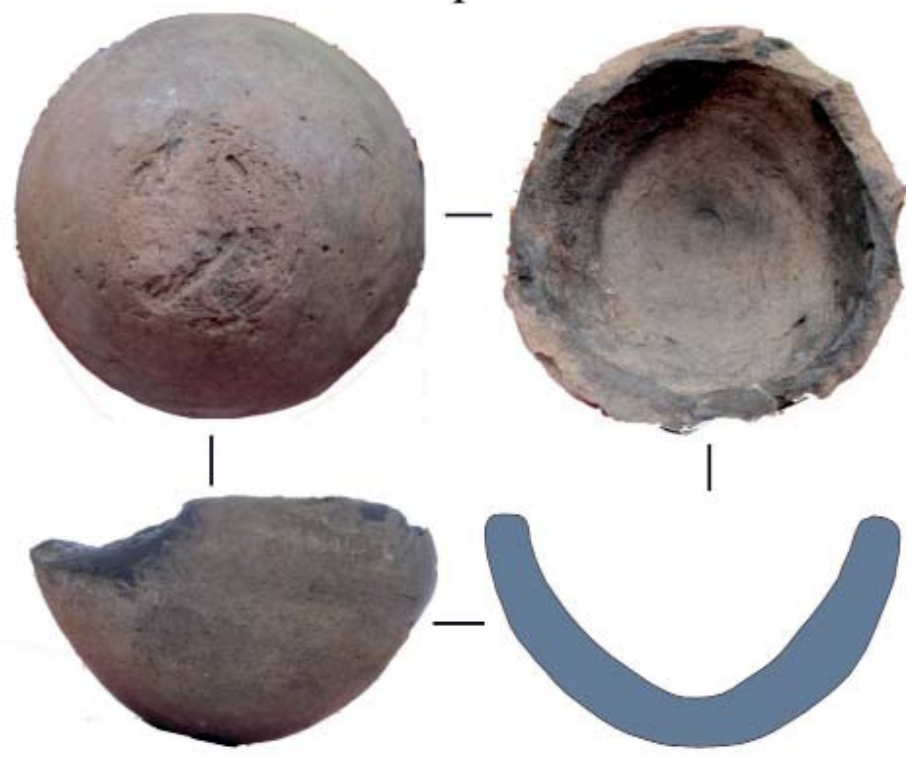

2

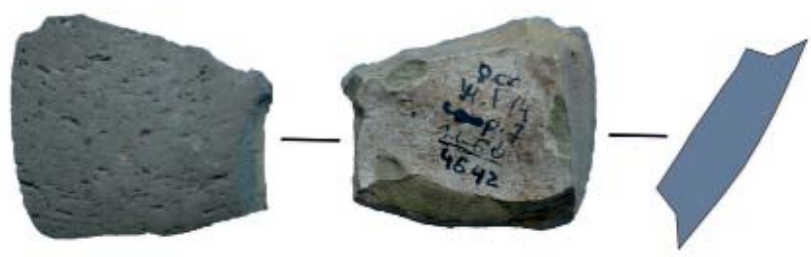

$\begin{array}{llll}0 & 1 & 2 & 3 \\ \mathrm{~cm}\end{array}$

L1 1

Рис. 3. Сероглиняные сфероконические сосуды: 1 - сфероконус типа IV (шифр СФ-6) из слоя I; 2 - фрагмент сфероконуса импортного производства (шифр СФ-19).

Fig. 3. Gray-clay sphero-conical vessels: 1 - spherical cone type IV (code SF-6) from layer I; 2 - fragment of a spherical cone of foreign manufacture (code SF-19).

сырьё, из которого изготовлены сфероконусы проанализированной серии, можно разделить на незапесоченное (небольшое количество пылевидного песка и редкие включения более крупных включений), слабозапесоченное (большое или среднее количество пылевидного песка и до 30-40 песчаных включений размером 0,15-0,5 мм), среднезапесоченное (большое количество пылевидного песка и 45-60 песчаных включений размером 0,15-0,6 мм) и сильнозапесоченное (большое количество пылевидного песка и до 200 включений размером $0,15-0,5)$.

В большинстве случаев для изготовления сфероконусов двух основных типов использованы слабозапесоченные глины (80-89\%). Использование сильнозапесоченного пластичного сырья зафиксировано в единичных случаях. Для изготовления сосуда типа IV использовались среднезапесоченные глины, а для импортного сосуда - смесь глин (рис. 6:
5). Также смесь глин зафиксирована в составе одного из сосудов типа III (табл. 2; рис. 6: 2).

В качестве способов подготовки исходного пластичного сырья зафиксированы только высушивание и дробление в сухом состоянии. Такой способ подготовки сырья зафиксирован в изготовлении сосудов как раннего, так и позднего типов. Наиболее заметно представлен среди сосудов раннего типа (I-II) - до $55 \%$. Для изготовления сосудов типа III чаще использовалась глина в естественно увлажнённом состоянии - до 80\% (табл. 3 ).

В качестве исходного непластичного сырья (ИНС) зафиксировано органическое и минеральное сырьё. Органическое сырьё представлено выжимкой из навоза жвачных животных, а также другой органический раствор неизвестного происхождения. Выжимка фиксируется по единичным отпечаткам от сильно измельчённых остатков травянистой растительности или скоплению таких отпечатков. 

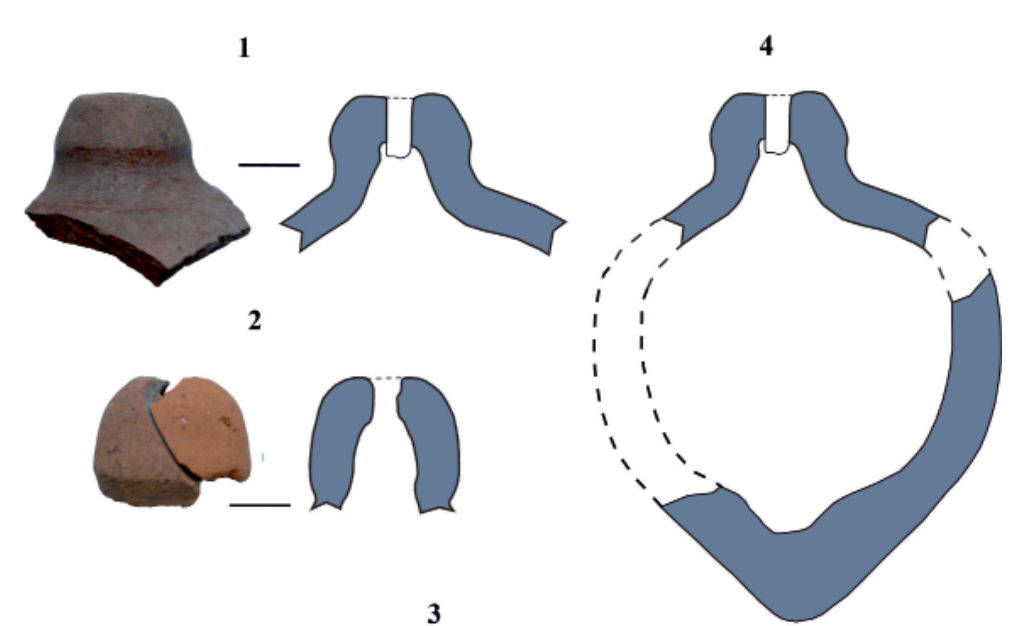

3

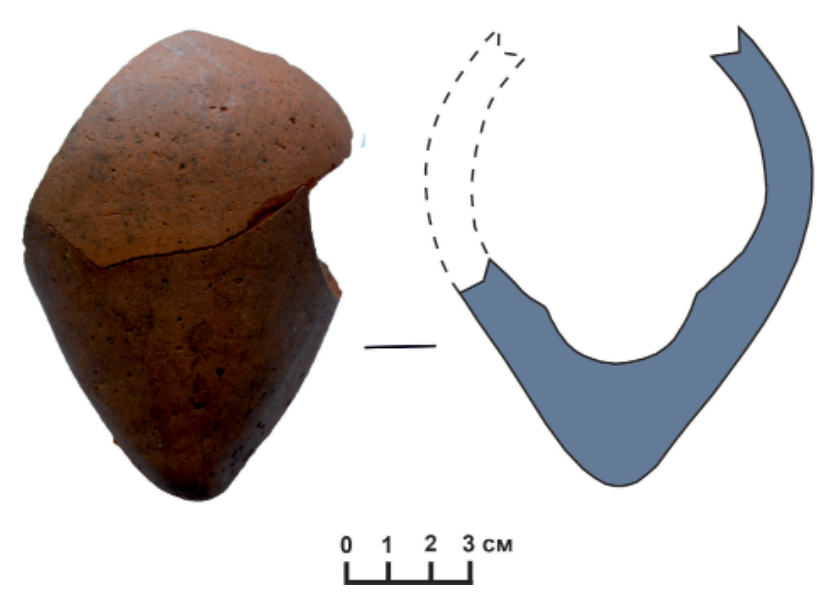

Рис. 4. Сфероконические сосуды типов I-II: 1 - фрагмент верхней части сфероконуса (СФ-12) из IV позднего слоя ; 2 - горло сфероконуса (шифр СФ-5) из слоя IV поздний; 3 - фрагмент сфероконуса (шифр СФ-17) из слоя II; 4 - реконструкция сфероеонического сосуда типа I-II.

Fig. 4. Sphero-conical vessels of types I-II: 1 - fragment of the upper portion of a spherical cone (SF-12) from the late layer IV; 2 - throat of a spherical cone (code SF-5) from the late layer IV; 3 - fragment of a spherical cone (code SF-17) from layer II; 4 - reconstruction of a type I-II sphero-conical vessel.

Иногда в отпечатках сохраняются углисточерные остатки от выгоревшей органики. Основная масса таких отпечатков имеет размер 0,5-1 мм, редко встречаются стеблевидные отпечатки размером 2-5 мм. В качестве признаков органического раствора выделено наличие полостей различной морфологии (округлые, воронки, аморфные, щели), а также аморфные участки, покрытые блестящими пленками буро-коричневого цвета. Размер полостей и отдельных плёнок не более 2 мм. В качестве минерального сырья зафиксированы песок и дресва. Песок представлен мелкой фракцией из разноцветный окатаных и полуокатаных зёрен размером 0,5-1 мм (рис. 7: 4). Дресва представляет собой породные обломки бело-серого цвета угловатые, трещиноватые и неокатаные по форме, размер основной фракции до 1 мм, единично зафиксированы крупные окатаные обломки размером до 5 мм (рис. 7: 1-3).

Ступень 4 - подготовка формовочной мaccb (ФМ). В навыках подготовки формовочных масс выделены первое и третье направления (Бобринский, 1978, с. 84-99). Первое направление представлено формовочными массами, состоящими из пластичного сырья без добавления каких-либо примесей. В рамках этого направления зафиксирован только один рецепт, в основе которого слабозапесоченная глина. Формовочные массы данного направления составляют примерно треть всех рецептов ФМ для сосудов раннего и позднего типов. В рамках третьего направления выявлены как рецепты с примесями уменьшающими отрицательное влияние усадки глины на сосуд во время их сушки и обжига (Класс I: органические примеси), так 
Таблииа 2. Исходное пластичное сырьё (ИПС)

Table 2. Starting plastic raw materials (IPS)

\begin{tabular}{|c|c|c|c|c|c|c|}
\hline ИПС ${ }^{1} /$ ТИП & I-II & III & IV & ИМП & $?$ & ВСЕГО \\
\hline$\Gamma$ & $1(11,1)$ & & & & & \\
\hline$\Gamma I$ & $8(88,9)$ & $8(80)$ & & & $2(66,7)$ & $18(75)$ \\
\hline$\Gamma I I$ & & & 1 & & & $1(4,2)$ \\
\hline IIII & & $1(10)$ & & & & $2(8,3)$ \\
\hline$\kappa T$ & & & & 1 & & $1(4,2)$ \\
\hline KTI & & $1(10)$ & & & $1(33,3)$ & $2(8,3)$ \\
\hline ВСЕГО & $9(100 \%)$ & $10(100 \%)$ & $1(100 \%)$ & $1(100 \%)$ & $3(100 \%)$ & $24(100 \%)$ \\
\hline
\end{tabular}

${ }^{1}$ ИПС-исходноепластичноесырьё, Г-незапесоченная, ГІ-слабозапесоченная глина, ГІІ-среднезапесоченная глина, ГІІІ - сильнозапесоченная глина, КТ - незапесоченная смесь глин, КТІ - слабозапесоченная смесь глин.

Таблица 3. Способы обработки ИПС (\%)

Table 3. IPS processing methods (\%)

\begin{tabular}{|c|c|c|c|c|c|c|}
\hline СОСТОЯНИЕ ИПС/ ТИП & I-II & III & IV & ИМП & ? & ВСЕГО \\
\hline Дроблёное в сухом состоянии & $5(55,6)$ & $2(20)$ & & 1 & $2(66,7)$ & $\mathbf{1 0}(\mathbf{4 1 , 7 )}$ \\
\hline $\begin{array}{c}\text { Естественно увлажнённое } \\
\text { состояние }\end{array}$ & $4(44,4)$ & $8(80)$ & 1 & & & $\mathbf{1 3}(\mathbf{5 4 , 2})$ \\
\hline Смесь: увлажнеённое +сухое & & & & & $1(33,3)$ & $\mathbf{1}(4,1)$ \\
\hline ВСЕГО & $\mathbf{9 ( 1 0 0 \% )}$ & $\mathbf{1 0 ( 1 0 0 \% )}$ & $\mathbf{1 ( 1 0 0 \% )}$ & $\mathbf{1 ( 1 0 0 \% )}$ & $\mathbf{3}(\mathbf{1 0 0 \% )}$ & $\mathbf{2 4}(\mathbf{1 0 0 \% )}$ \\
\hline
\end{tabular}

Таблица 4. Рецепты формовочных масс (ФМ)

Table 4. Formulations of molding compounds (FM)

\begin{tabular}{|c|c|c|c|c|c|c|}
\hline$\Phi M^{I}$ & I-II & III & IV & ИМП & $?$ & ВСЕГО (\%) \\
\hline$\Gamma I$ & $3(33,3)$ & $3(30)$ & & & & $6(25)$ \\
\hline$\Gamma I+B$ & $3(33,3)$ & $3(30)$ & & & $1(33,3)$ & $7(29,2)$ \\
\hline$\Gamma I I+B$ & & & 1 & & & $1(4,17)$ \\
\hline$\Gamma I I I+B$ & & $1(10)$ & & & & $2(8,3)$ \\
\hline$K T I+B$ & & $1(10)$ & & & $1(33,3)$ & $2(8,3)$ \\
\hline$\Gamma I+O P$ & $1(11,1)$ & $2(20)$ & & & & $3(12,5)$ \\
\hline$K T+O P$ & & & & 1 & & $1(4,17)$ \\
\hline$\Gamma I+\Pi$ & & & & & $1(33,3)$ & $1(4,17)$ \\
\hline$\Gamma+Д P+B$ & $1(11,1)$ & & & & & $1(4,17)$ \\
\hline$\Gamma I+\Pi+B$ & $1(11,1)$ & & & & & $1(4,17)$ \\
\hline ВСЕГО & $9(100 \%)$ & $10(100 \%)$ & $1(100 \%)$ & $1(100 \%)$ & $3(100 \%)$ & $24(100 \%)$ \\
\hline
\end{tabular}

1 ФМ - формовочная масса, ГІ - слабозапесоченная глины, ГІІ - среднезапесоченная Глина, ГІІІ сильнозапесоченная глина, КTI - слабозапесоченная смесь глин, КТ - незапесоченная смесь глин, В - выжимка из навоза жвачных животных, ОР - органический раствор, П - песок, ДР - дресва.

и рецепты с примесями, увеличивающими огнестойкость изделий (Класс II: минеральные примеси). Формовочные массы с органическими примесями составляют примерно половину всех рецептов для сосудов обоих типов. Наиболее распространены рецепты с выжимкой. Формовочная масса с минеральной примесью, а именно с мелким песком в средней концентрации, зафиксирована в одном случае для сфероконуса, тип которого определить не удалось. Навыки перечисленных направлений А.А. Бобринский считал обособленными (Бобринский, 1978, с. 93). Кроме обособленных навыков, в комплексе навыков подготовки ФМ гончаров, изготовлявших сфероконусы раннего типа (I-II), 

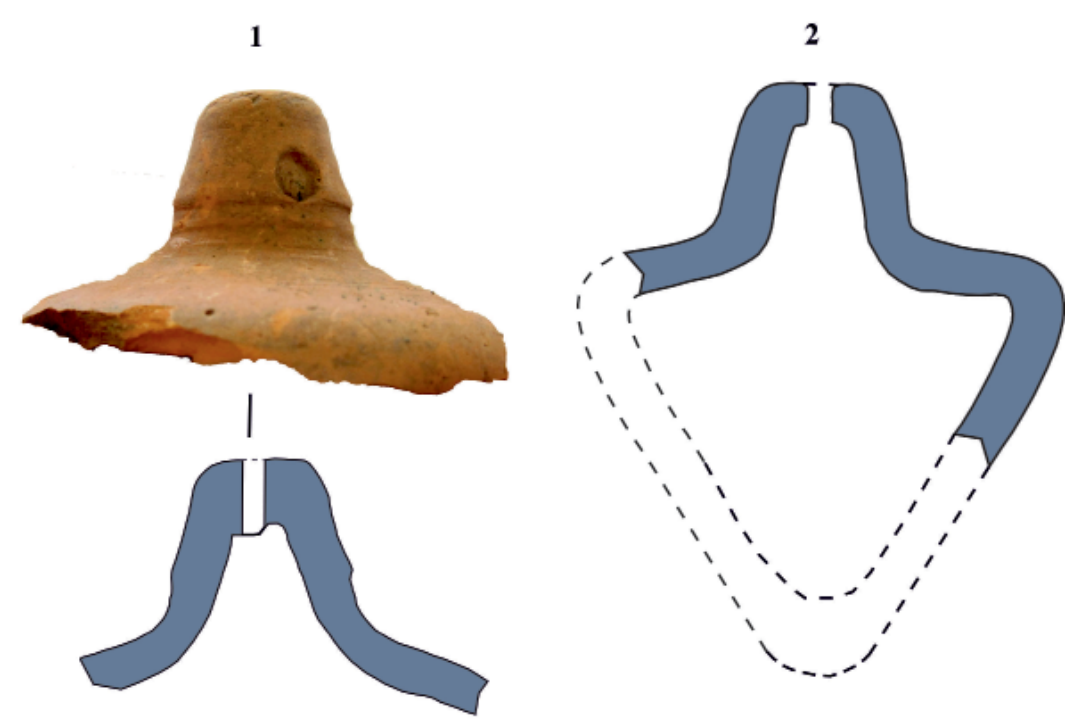

3

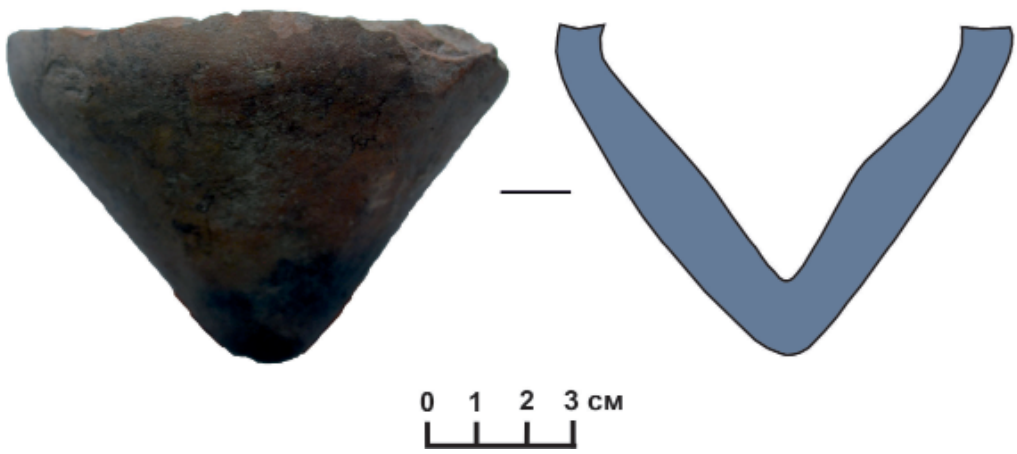

Рис. 5. Сфероконические сосуды типа III: 1 - верхняя часть сфероконуса типа III (шифр СФ-11) из слоя IV поздний; 2 - реконструкция сфероконического сосуда типа III; 3 - придонная часть сфероконуса (шифр СФ-16) из землянки 30-40-х гг. XIV вв. (сооружение 67).

Fig. 5. Sphero-conical vessels of type III: 1 - upper portion of a spherical cone of type III (code SF-11) from the late layer IV; 2 - reconstruction of a type III sphero-conical vessel; 3 - bottom portion of a spherical cone (code SF-16) from a dugout of the 1330-40s (building 67).

зафиксированы смешанные навыки подготовки ФМ. Данный комплекс навыков представлен рецептами, в которых присутствуют как минеральные, так и органические примеси это рецепты с примесью дресвы или песка в средней концентрации и выжимки (табл. 4).

Стадия II - созидательная. Ступень 5 конструирование начина (H). В изготовлении начина для сосудов разных типов зафиксированы разные способы скульптурной лепки в совокупности с использованием формы-модели (табл. 5). В большинстве случаев начин был неполным глубоким и представлял собой всю нижнюю часть сосуда от места наибольшего диаметра до основания. Особенно четко выделяется у сосудов позднего типа. У сосудов раннего типа данный переход сглажен ввиду того, что начин у них менее глубокий. Конструирование начина у сосудов этого типа начиналось с заполнения дна формы-ёмкости порцией формовочной массы. Данный приём обеспечивал значительное утолщение стенок в основании тулова и уплощение дна внутри самой ёмкости (рис. 8: 1-2). Начины сосудов типа I-II могли изготовляться двумя основными способами, в основе которых лоскутный налеп, использование формы-ёмкости в совокупности с донно-ёмкостной или ёмкостнодонной программой (рис. 8). Начины сосудов типа III изготовлялись тремя основными способами - зафиксировано несколько способов скульптурной лепки (лоскутный налеп, спиралевидный налеп из жгутов или лент) использование как формы-ёмкости, так и формы-основы, донно-ёмкостная и ёмкостнодонная программы (рис. 9).

Ступень 6 - конструирование полого тела (ПТ). Основным способом изготовления полого тела для сосудов обоих типов было вытягивание его из жгута, наложенного по пери- 
Таблица 5. Способы изготовления начинов $(\mathrm{H})$

Table 5. Methods for producing fillings $(\mathrm{N})$

\begin{tabular}{|c|c|c|c|c|c|c|c|c|}
\hline \multicolumn{3}{|c|}{ ТЕХНИЧЕСКИЕ СОСТАВЛЯЮЩИЕ } & \multicolumn{6}{|c|}{ ТИПЫ СФЕРОКОНУСОВ } \\
\hline ПРОГРАММА & МОДЕЛЬ & $\begin{array}{c}\text { CTP. } \\
\text { ЭЛЕМЕНТ }\end{array}$ & I-II & III & IV & ИМП & $?$ & $\begin{array}{c}\text { ВСЕГО } \\
(\%)\end{array}$ \\
\hline \multirow{3}{*}{ Д- $\ddot{E}$} & \multirow{2}{*}{$\Phi-\ddot{E}$} & лоскут & $2(22,2)$ & & 1 & & & $3(12,5)$ \\
\hline & & жгуm & & $1(10)$ & & & & $1(4,17)$ \\
\hline & $\Phi-O$ & лоскут & & $1(10)$ & & & & $1(4,17)$ \\
\hline \multirow{2}{*}{$\ddot{E}-Д$} & $\Phi-\ddot{E}$ & лоскут & $1(11,1)$ & & & & & $1(4,17)$ \\
\hline & нет & лента & & $1(10)$ & & & & $1(4,17)$ \\
\hline$?$ & $\Phi-\ddot{E}$ & $?$ & & $2(20)$ & & & & $2(8,3)$ \\
\hline \multirow{3}{*}{ ? } & \multirow{3}{*}{ ? } & $?$ & $5(55,6)$ & $4(40)$ & & 1 & 3 & $13(54,2)$ \\
\hline & & лоскут & & $1(10)$ & & & & $1(4,17)$ \\
\hline & & жсунm & $1(11,1)$ & & & & & $1(4,17)$ \\
\hline \multicolumn{3}{|c|}{ ВСЕГО } & $9(100 \%)$ & $\begin{array}{c}10 \\
(100 \%)\end{array}$ & $\begin{array}{c}1 \\
(100 \%)\end{array}$ & $\begin{array}{c}1 \\
(100 \%)\end{array}$ & $\begin{array}{c}3 \\
(100 \%)\end{array}$ & $24(100 \%)$ \\
\hline
\end{tabular}

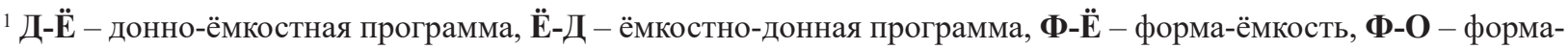
основа.

Таблица 6. Способы изготовления полого тела (ПТ)

Table 6. Methods for producing hollow bodies (PT)

\begin{tabular}{|c|c|c|c|c|c|c|}
\hline СПОСОБ & I-II & III & IV & ИМП & ? & ВСЕГО (\%) \\
\hline вытягивание & $6(66,7)$ & $2(20)$ & & & $1(33,3)$ & $\mathbf{9}(\mathbf{3 7}, \mathbf{5})$ \\
\hline скульптурная лепка & $1(11,1)$ & $2(20)$ & & & & $\mathbf{3}(\mathbf{1 2 , 5})$ \\
\hline$?$ & $2(22,2)$ & $6(60)$ & 1 & 1 & $2(66,7)$ & $\mathbf{1 2}(\mathbf{5 0})$ \\
\hline ВСЕГО & $\mathbf{9 ( 1 0 0 \% )}$ & $\mathbf{1 0}(\mathbf{1 0 0 \% )}$ & $\mathbf{1 ( 1 0 0 \% )}$ & $\mathbf{1 ( 1 0 0 \% )}$ & $\mathbf{3 ( 1 0 0 \% )}$ & $\mathbf{2 4}(\mathbf{1 0 0 \% )}$ \\
\hline
\end{tabular}

метру начина (рис. 10). В единичных случаях фиксируется изготовление полого тела спиралевидным налепом из жгутов или лоскутов (табл. 6)

Ступень 7 - формообразование сосудов $(\Phi)$. Зафиксировано два основных способа придания сосудам формы - использование форм-моделей и использование гончарного круга. Первый приём характерен для придания формы начину - придонной части. В качестве формы-модели использовались пирамидки с четырьмя или шестью гранями. Отпечатки граней зафиксированы на внутренней поверхности сосудов (рис. 9: 3). Начин изготавливался способом налепливания строительных элементов внутри полой пирамидки или поверх неё. Для изготовления начина сфероконуса типа IV использована формаёмкость с округлым дном. Для завершения конструирования и формообразования сосуд был извлечён из формы-ёмкости и поставлен на зольную подсыпку (рис. 3: 1; 8: 3). Характерные следы зафиксированы в основании тулова. Для формообразования полого тела и сосуда в целом использовался гончарный круг. У сосудов, для изготовления которых использована форма-ёмкость, следы формообразования с помощью гончарного круга выражены сильнее. В зависимости от степени участия гончарного круга в конструировании и формообразовании сосуда можно выделить два уровня развития функций круга (РФК). Уровень РФК 4 (конструирование начина и полого тела осуществлялось способами скульптурной лепки, а формообразование с помощью гончарного круга) с определённой долей уверенности удалось зафиксировать только для одного из сосудов позднего типа (III). Массово для сосудов обоих типов фиксируется уровень РФК 6 (конструирование начина осуществлялось способом скульптурной лепки, а полое тело изготовлено с использованием гончарного круга) (табл. 7). Сочетание ручных и машинных способов в формообразовании одного сосуда позволяют определить смешанный характер навыков 
1

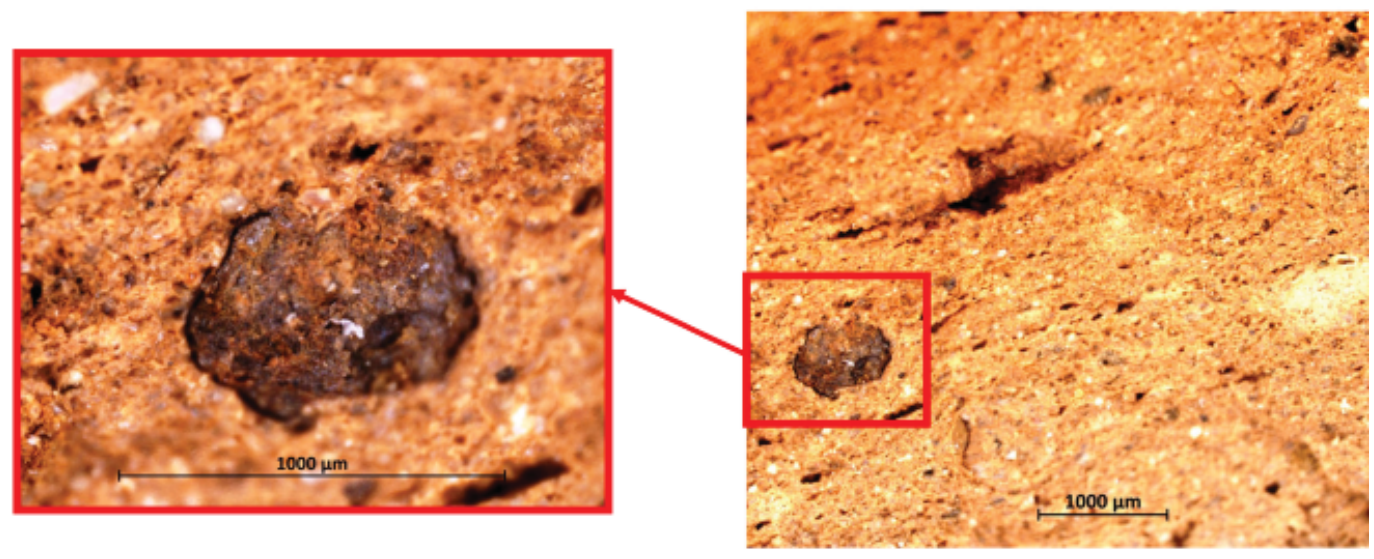

2

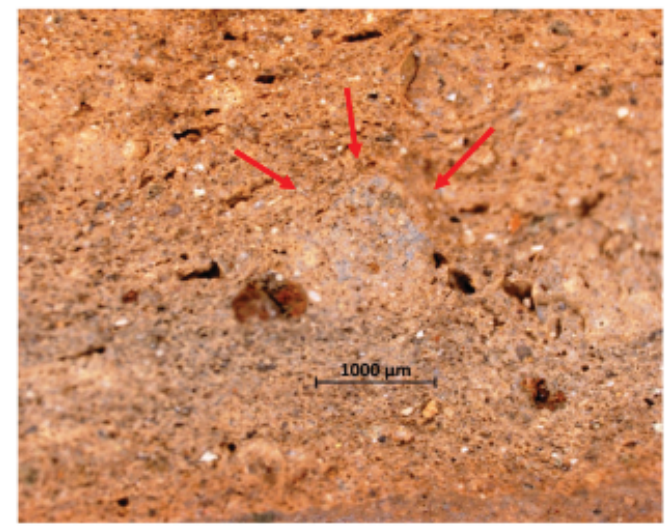

4

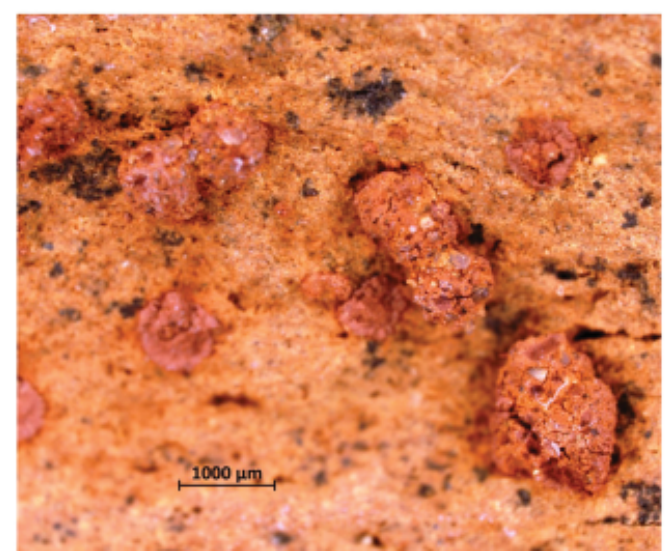

3

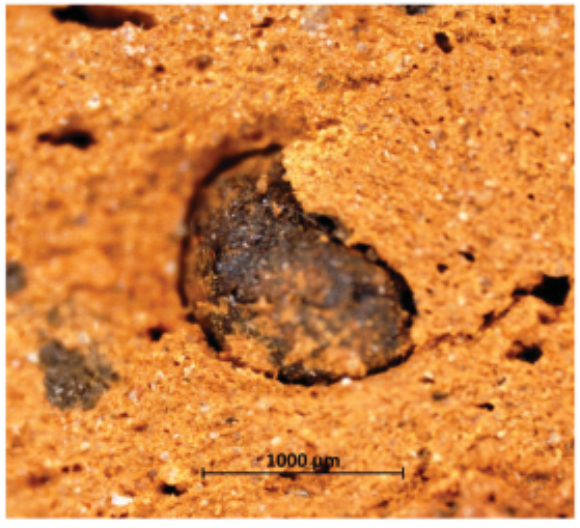

5

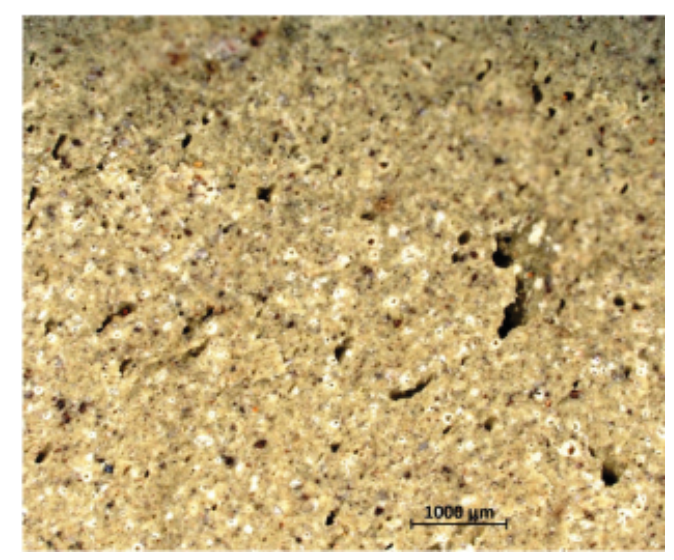

Рис. 6. Естественные включения в составе ИПС: 1 - неокатаный бурый железняк в составе незапесоченного сырья; 2 - включения незапесоченой тугоплавкой глины в составе смеси глин; 3 - окатаный бурый железняк в составе слабозапесоченой глины; 4 - железистые включения в составе слабозапесоченой глины; 5 - пластичное сырьё с включениями карбонатной крошки сфероконуса импортного происхождения.

Fig. 6. Natural inclusions in the composition of the IPS: 1 - non-rounded brown iron ore in the composition of nonoversanded raw materials; 2 - inclusions of non-oversanded high-melting clay in the composition of the clay mixture; 3 - rounded brown iron ore in the composition of slightly oversanded clay; 4 - ferruginous inclusions in the composition of slightly oversanded clay; 5 - plastic raw material with inclusions of the carbonate chips of a spherical cone of foreign manufacture. 


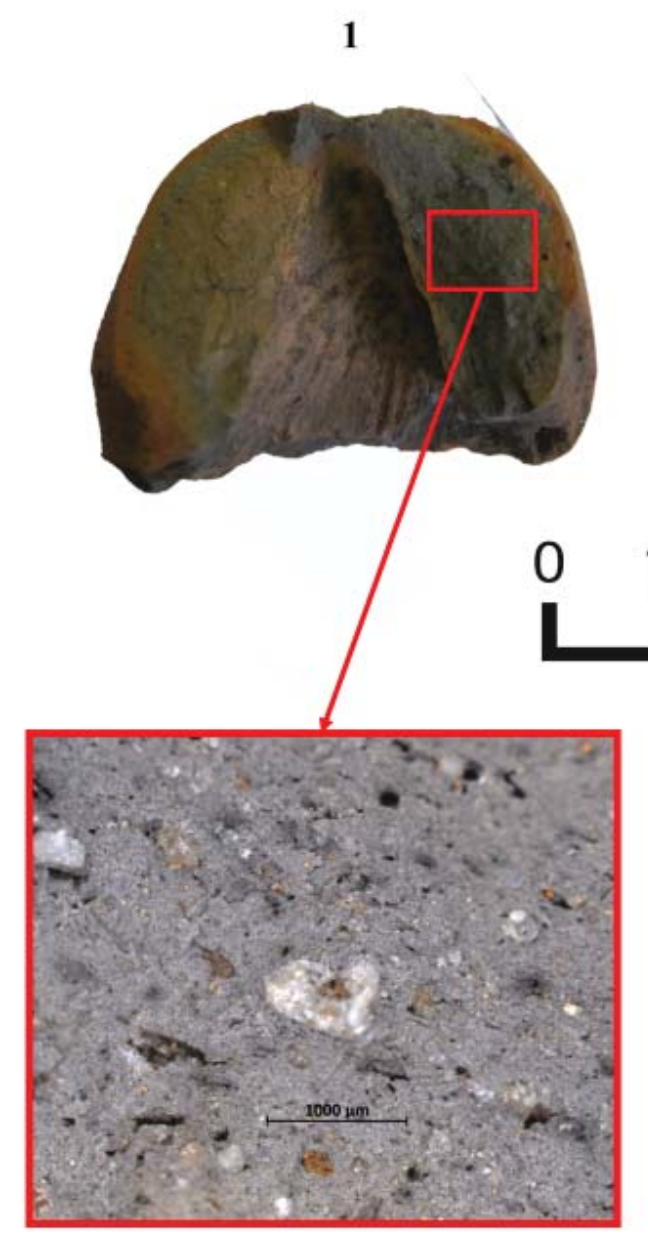

3

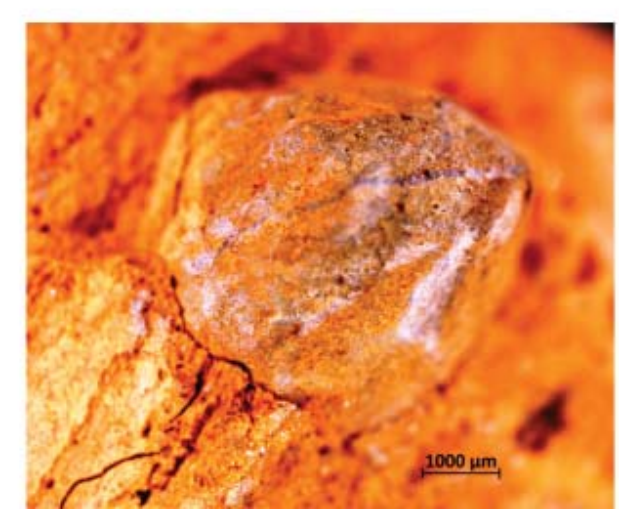

2

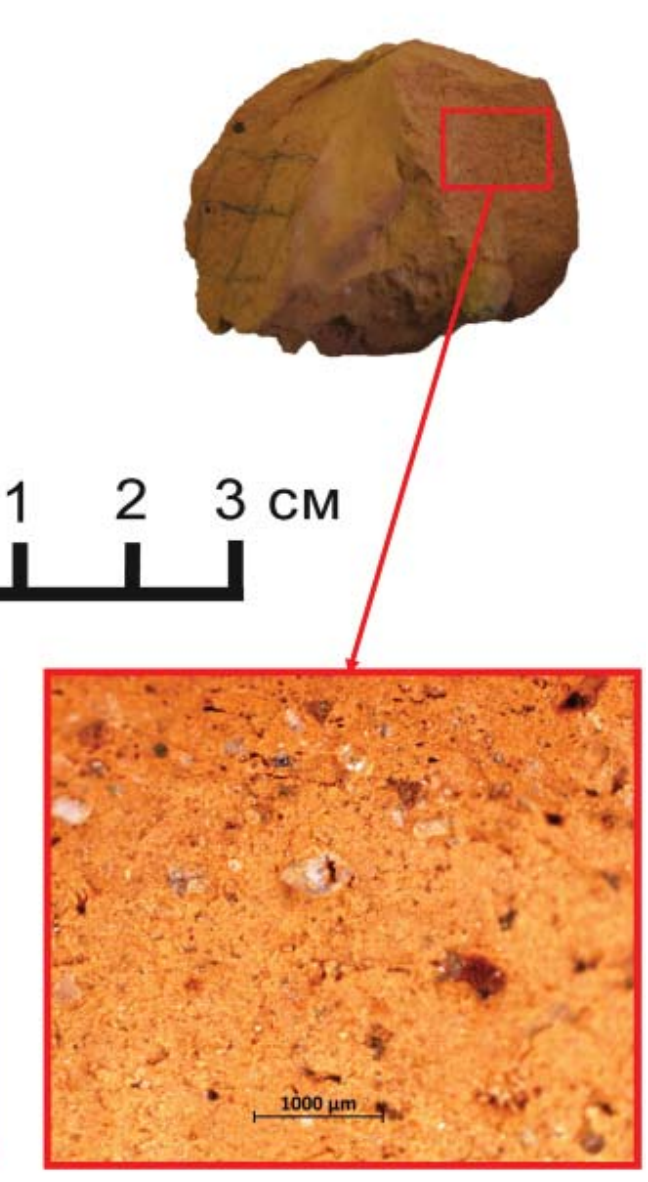

4

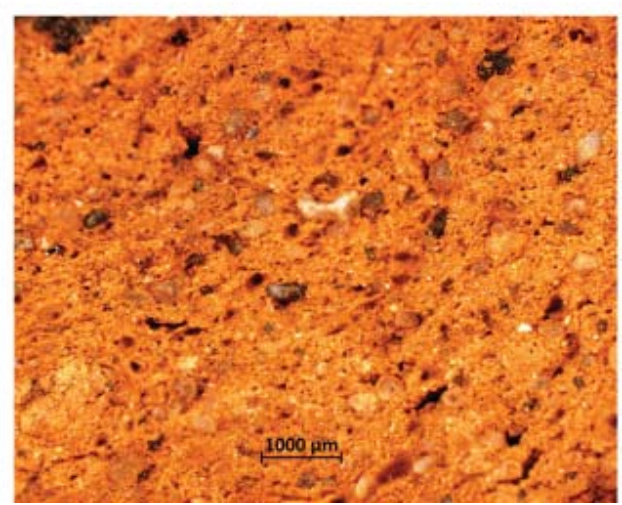

Рис. 7. Минеральные примеси в составе ФМ: 1 - примесь дресвы до вторичного обжига; 2 - примесь дресвы после вторичного обжига; 3 - крупный осколок дресвы.

Fig. 7. Mineral impurities in the composition of FM: 1 - gruss admixture before secondary firing; 2 - gruss admixture after secondary firing; 3 - large fragment of gruss. 
Таблица 7. Уровни развития функций гончарного круга (РФК)

Table 7. Potter's wheel functionality development levels (RFK)

\begin{tabular}{|c|c|c|c|c|c|c|}
\hline РФК/ ТИП & I-II & III & IV & ИМП & $?$ & ВСЕГО (\%) \\
\hline 4 & & 1 & & & 2 & $3(12,5)$ \\
\hline 6 & 6 & 4 & & & 1 & $\mathbf{1 2}(\mathbf{5 0})$ \\
\hline $4-5$ & 1 & 2 & & & & $\mathbf{3}(\mathbf{1 2 , 5})$ \\
\hline $4-6$ & 2 & 3 & 1 & & & $\mathbf{5}(\mathbf{2 0 , 8})$ \\
\hline$?$ & & & & 1 & & $\mathbf{1}(\mathbf{4 , 1 7})$ \\
\hline ВСЕГО & $\mathbf{9 ( 1 0 0 \% )}$ & $\mathbf{1 0}(\mathbf{1 0 0 \% )}$ & $\mathbf{1 ( 1 0 0 \% )}$ & $\mathbf{1}(\mathbf{1 0 0} \%)$ & $\mathbf{3 ( 1 0 0 \% )}$ & $24(100 \%)$ \\
\hline
\end{tabular}

при выполнении этой технологической задачи у гончаров, изготовивших сфероконические сосуды изученной серии.

Ступень 8- обработка поверхности (ОП). Выявлено несколько способов обработки поверхности: машинное заглаживание внутренней и внешней поверхности зафиксировано для всех сосудов; обстругивание в придонной части сосуда; выбивание колотушкой с гладкой поверхностью; лощение. Самым распространённым способом кроме машинного заглаживания является лощение. Для сосудов обоих типов характерно вертикальное чересполосное лощение придонной части. Лощение верхней части сосуда характерно, главным образом, для сосудов типа I-II (табл. 8). Для сосуда импортного происхождения зафиксировано ангобирование внутренней поверхности.

Стадия III - закрепительная. Ступени 9 и 10 - придание сосудам прочности и устранение влагопроницаемости. В качестве основных способов выполнения данной технологической задачи в производстве сосудов данной серии можно выделить воздушное высушивание и термическую обработку - обжиг. Отсутствие растрескивания сосудов и видимой их деформации свидетельствует о предварительном полном воздушном высушивании сосудов и последующим их обжигом с соблюдением определенной технологической схемы. Большинство сосудов данной серии имеет равномерную окрашенность внешних поверхностей в красно-коричневый или жёлто-коричневый цвет. Изломы сосудов нередко имеют неравномерную прокалённость - зафиксированы прослойки серого цвета разной мощности и насыщенности. Несмотря на это обстоятельство, обжиг данных сфероконусов производился в окислительной газовой среде при температурах каления глины с использовани- ем специального теплотехнического сооружения - горна. Наличие прослоек в изломах может объясняться большой толщиной стенок сосудов (у некоторых сосудов мощность стенок в придонной части доходит до 2 см) и специфической формой самих сфероконусов (имеют очень узкое горловое отверстие, в большинстве случаев 0,5-0,7 мм). Эти обстоятельства препятствуют получению в результате обжига равномерной прокалённости стенок и поверхностей сосудов. В результате вторичного обжига в лабораторных условиях при 900 градусах, образцы сосудов приобрели более насыщенный цвет, стенки и поверхности приобрели равномерную окраску. Данные наблюдения позволяют предполагать, что обжиг данных сосудов производился при температуре не более 900 градусов (рис. 11: 3).

Из всей серии выделяются только два сосуда - это сфероконус типа IV и сфероконус импортного происхождения. Первый - имеет равномерную светло-серую окраску поверхностей и темно-серую окраску излома. После вторичного обжига образец от этого сосуда приобрёл равномерную красно-коричневую окраску, что позволяет охарактеризовать его термическую обработку как обжиг в восстановительной газовой среде (без доступа кислорода на протяжении всего времени обжига) (рис. 11:2). Фрагмент от сфероконуса импортного происхождения изначально имел серую окраску поверхностей и трёхслойную окраску излома с более светлой, бежевой с чёткими границами, прослойкой в середине. В результате вторичного обжига внешняя поверхность не изменила цвет, а прослойка в изломе не исчезла, только стала чуть светлее (рис. 11: 1). Данные наблюдения позволяют подтвердить предположение о том, что для изготовления данного сфероконического сосуда была 


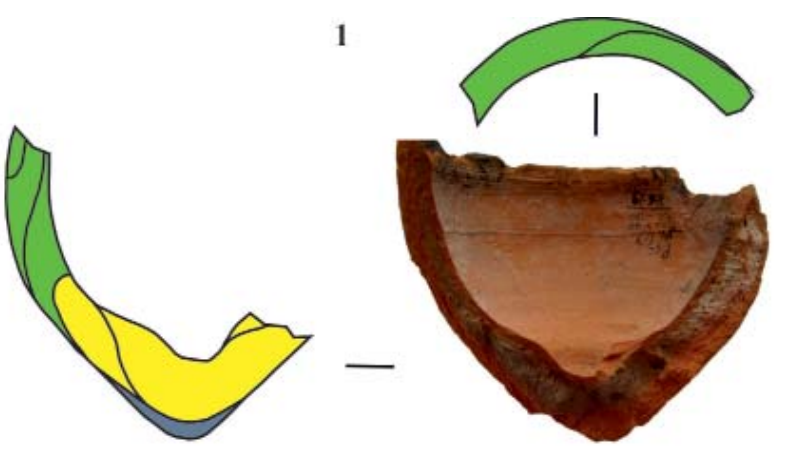

2

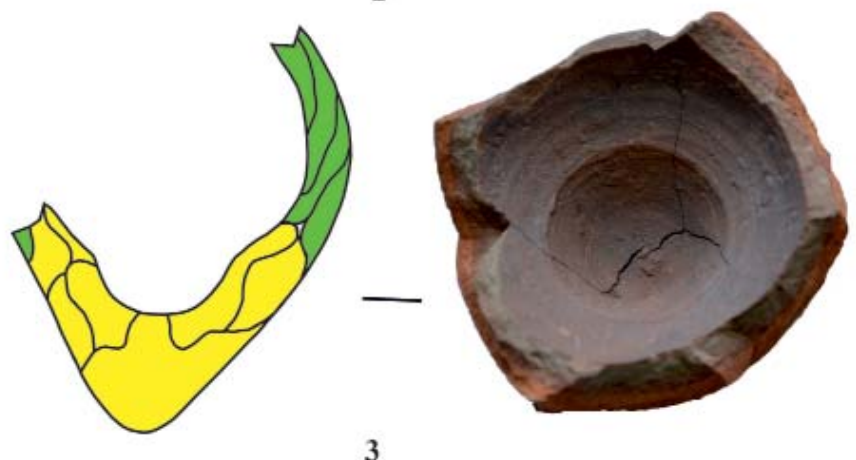

3

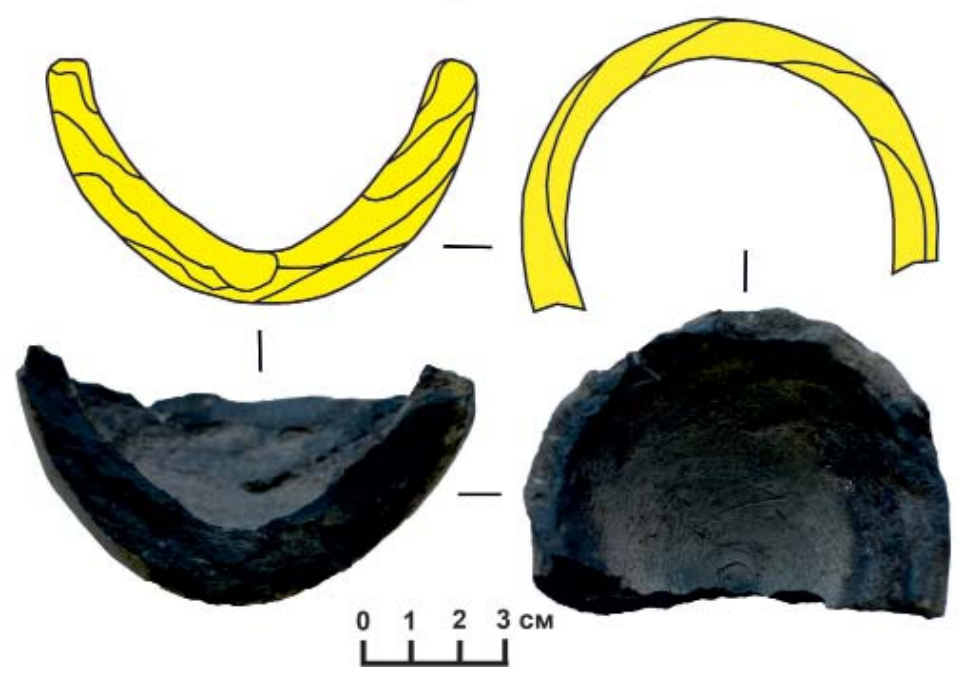

Рис. 8. Конструирование начина способом лоскутного налепа в соответствие с Д-ё программой с использованием Ф-Ё: 1 - сфероконус типа I-II (СФ-22); 2 - сфероконус типа I-II (СФ-17); 3 - сфероконус типа IV (СФ-6).

Fig. 8. Preparation of the filling using the patchwork molding technique in accordance with the bottom-capacitive

(D-E) program using the F-E: 1 - spherical cone type I-II (SF-22); 2 - spherical cone type I-II (F-17); 3 - spherical cone type IV (SF-6).

использована слабо ожелезнённая или неожелезнённая глина, а обжиг производился в окислительной газовой среде при температуре, вероятно, более 900 градусов.

Результаты изучения сырьевой базы для изготовления сфероконических сосудов. Для определения потенциальной сырьевой базы гончаров, изготовивших сфероконусы изученной выборки, была использована база образцов глинистого сырья, которая была сформирована по итогам обследования
Болгарского городища и его близлежащих территорий в радиусе 10 км (рис. 12). Данные методов физико-химической аналитики образцов сырья, методика и результаты сопоставления его с сериями неполивной керамики Болгарского городища опубликованы нами ранее (Бахматова, Ситдиков, 2017, с. 255-281). Для сопоставления образцов сосудов и глинистого сырья были использованы две категории данных - характеристика состава по данным бинокулярного анализа и макро и микро- 
Таблица 8. Виды лощения сфероконических сосудов Table 8. Types of polishing of sphero-conical vessels

\begin{tabular}{|c|c|c|c|c|c|c|c|}
\hline ЧАСТЬ СОСУДА & ЛОЩЕНИЕ & I-II & III & IV & ИМП & $?$ & $\begin{array}{c}\text { ВСЕГО } \\
(\%)\end{array}$ \\
\hline \multirow{5}{*}{$\begin{array}{c}\text { верхняя часть } \\
\text { (плечо) }\end{array}$} & $\begin{array}{c}\text { вертикальное } \\
\text { сплошное }\end{array}$ & 1 & & & & & $1(4,17)$ \\
\hline & $\begin{array}{c}\text { вертикальное } \\
\text { чересполосное }\end{array}$ & 1 & & & & & $1(4,17)$ \\
\hline & $\begin{array}{c}\text { горизонтальное } \\
\text { сплошное }\end{array}$ & 2 & & & & & $2(8,3)$ \\
\hline & $\begin{array}{c}\text { горизонтальное } \\
\text { чересполосное }\end{array}$ & & 1 & & & & $1(4,17)$ \\
\hline & нет & 2 & 3 & & & 1 & $6(25)$ \\
\hline \multirow{4}{*}{$\begin{array}{c}\text { нижняя часть } \\
\text { (придонная часть) }\end{array}$} & $\begin{array}{l}\text { вертикальное } \\
\text { сплошное }\end{array}$ & & & & & 1 & $1(4,17)$ \\
\hline & $\begin{array}{l}\text { вертикальное } \\
\text { чересполосное }\end{array}$ & 2 & 4 & & & 1 & $7(29,2)$ \\
\hline & $\begin{array}{c}\text { горизонтальное } \\
\text { сплошное }\end{array}$ & & & 1 & & & $1(4,17)$ \\
\hline & нет & 1 & 2 & & 1 & & $4(16,6)$ \\
\hline \multicolumn{2}{|c|}{ ВСЕГО } & $9(100 \%)$ & $10(100 \%)$ & $1(100 \%)$ & $1(100 \%)$ & $\begin{array}{c}3 \\
(100 \%)\end{array}$ & $24(100 \%)$ \\
\hline
\end{tabular}

элементный составы по данным эмиссионного спектрального анализа. Сопоставление с образцами сырья не проводилось для тех сосудов, в составе которых зафиксированы смеси глин, а также сосудом явно импортного происхождения (рис. 3: 2).

Сравнение данных бинокулярного анали3a. Анализ качественного и количественного составов естественных примесей в исходном пластичном сырье сфероконических сосудов позволил разделить их на 13 групп, отождествляемых с «условными районами» отбора ИПС (Бобринский, 1999, с. 5-110). Главными дифференцирующими признаками при разделении стали морфология зёрен песка, а также наличие или отсутствие бурых железняков и других железистых включений, карбонатов (табл. 9).

Большинство образцов глинистого сырья характеризуется большим количеством песка в составе (от 80 до 500 и более включений на площади в $1 \mathrm{~cm}^{2}$ ). Результаты сопоставления показали, что состав ИПС сфероконусов, объединённых условным районом отбора сырья Р5 (сосуд СФ-3) схож с составом образцов глинистого сырья с шифрами г 7-3, БГ 14-4, БГ 14-6 (рис. 12). Данные образцы сырья отобраны в местах, достаточно удалённых друг от друга. Найдено соответствие составов только относительно сфероконуса и образцов сырья с высокой степенью запесоченности.
Традиция использования глины такого качества в производстве сфероконических сосудов зафиксирована единично. Наиболее характерно для изготовления сфероконусов использование слабозапесоченных глин. Такие глины зафиксированы в базе образцов сырья (образцы БГ 14-9 и БГ 14-10), но среди составов ИПС сфероконусов для них не было найдено аналогий, в первую очередь, по морфологии зёрен песчаных включений и отсутствию в этих образцах глин железистых включений, которые характерны для сырья, из которого сделаны большинство изученных сфероконусов.

Сравнение макро и микроэлементного состава образиов. В рамках комплексного изучения данной серии сфероконических сосудов было отобрано по три пробы с излома каждого сосуда - со стороны внешней поверхности, середины излома, со стороны внутренней поверхности. Для сопоставления были взяты средние значения распределения макро и микроэлементов в каждом отдельном сфероконусе. В результате сопоставления получено несколько групп совпадений вокруг образцов сырья под шифрами БГ 14-2, БГ 14-9, БГ 14-10 (отобраны в подгорной части, на островах), БГ 14-4 и БГ 14-5 (отобраны к западу от городища), БГ 14-6 (отобран в нагорной части городища вблизи раскопа $\mathrm{CC}$ ). 


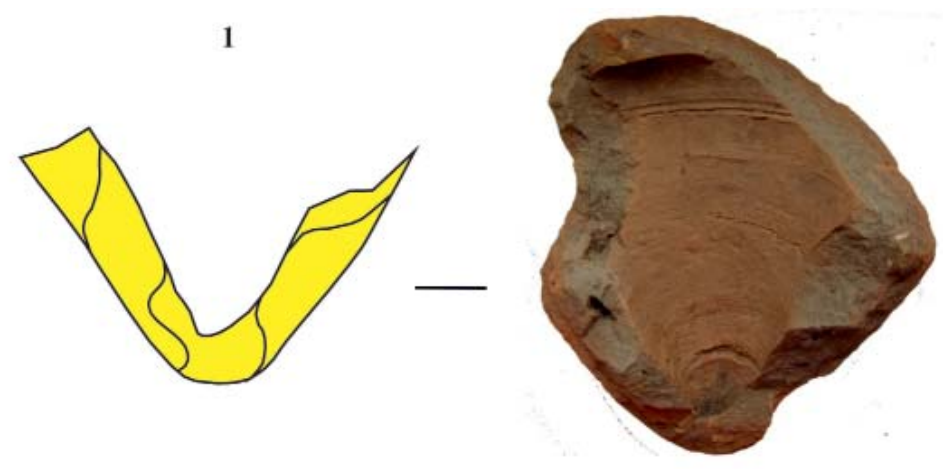

2

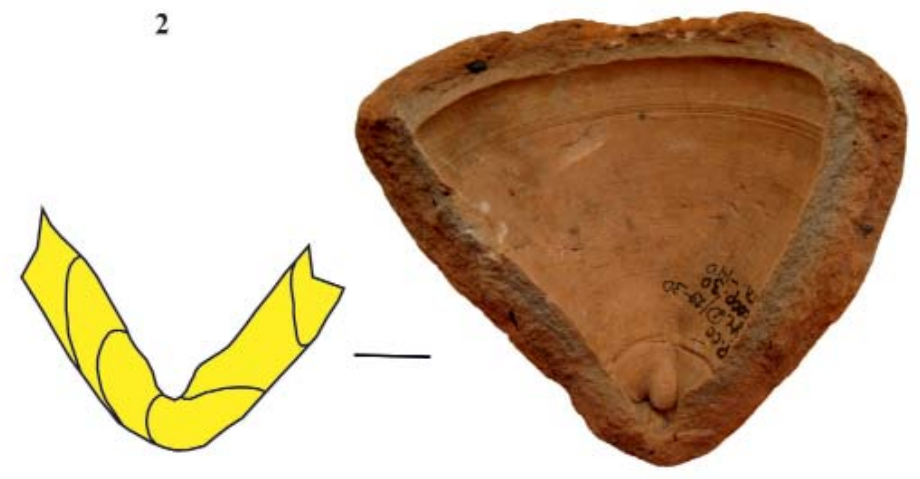

3
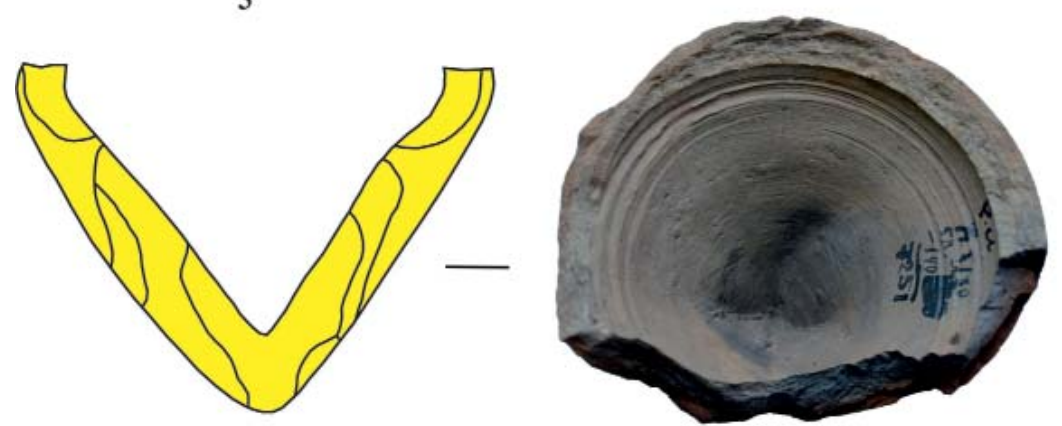

$\begin{array}{llll}0 & 1 & 2 & 3 \\ \mathrm{~cm}\end{array}$

Рис. 9. Способы конструирования начинов сосудов типа III: 1 - Ё-Д начин из лент без использования формымодели (СФ-2); 2 - по Д-Ё программе спирально-жгутовым налепом с использованием Ф-Ё (СФ-1);

3 - по Д-Ё программе способом лоскутного налепа с использованием Ф-О (СФ-16).

Fig. 9. Methods for preparing the fillings of type III vessels: 1 - E-D filling made of ribbons without using a formmodel (SF-2); 2 according to the D-E program by means of spiral-bundle molding using F-E (SF-1); 3 - according to the D-E program by means of patchwork molding using F-O (SF-16).

Из перечня всех совпадений наиболее достоверным можно считать только совпадения, связанные с одним из сфероконусов типа III (сосуд с шифром СФ-3) с характеристиками ИПС, соответствующих условному району отбора сырья Р5 и образцом глинистого сырья с шифром БГ 14-4. Совпадения составов этой пары образцов зафиксированы при анализе обеих категорий данных.

Обсуждение результатов. Наличие в Болгаре собственного производства сфероконусов не вызывает сомнений. Об этом свиде- тельствуют результаты исследования объектов производственного характера с бракованными сфероконусами. Производились красноглиняные сосуды всех типов, которые были выделены Т.А. Хлебниковой. Ранний (I-II) и поздний (III) типы сосудов изученной серии были произведены в золотоордынское время. Навыки конструирования и формообразования сосудов исследователи считают наиболее устойчивыми - субстратными, а навыки отбора ИПС и подготовки ФМ менее устойчивыми - приспособительными (Бобринский, 1978, 
1

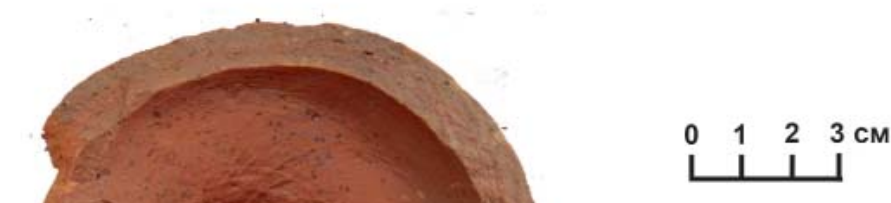

3

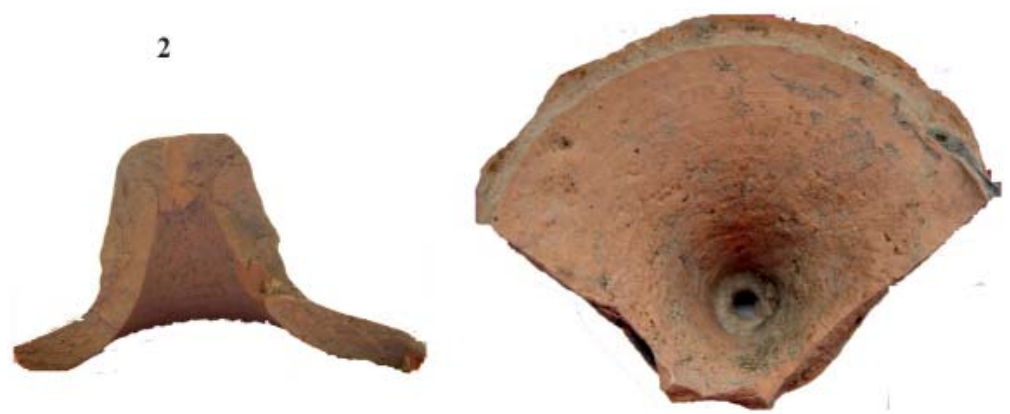

Рис. 10. Верхние части сфероконусов со следами их вытягивания: 1 - внутренняя повехность сосуда типа I-II (СФ-14); 2 - излом сосуда типа III (СФ-11); 3 - внутренняя поверхность сосуда типа III (СФ-10).

Fig. 10. Upper portions of the spherical cones with traces of elongation: 1 - internal surface of a type I-II vessel $(\mathrm{SF}-14) ; 2$ - fracture of a type III vessel $(\mathrm{SF}-11) ; 3$ - inner surface of a type III vessel (SF-10).

с. 242-264; Цетлин, 2012, с. 134-135). Характеристика состава двух категорий навыков позволяет охарактеризовать этапы смешения технологических традиций (Цетлин, 2012, с. 134-135). Первый этап проявился в наличии смесей глин в составе ФМ сосудов. Отражает процесс приспособления гончаров позднего золотоордынского времени, изготовлявших сфероконусы типа III к сырьевой базе при переселении в новое место - Болгар. Второй этап - смешение традиций на этапе подготовки ФМ - зафиксирован для сосудов раннего типа I-II - рецепт ФМ на основе слабозапесоченной глины с примесью песка и выжимки из навоза. Простой рецепт с примесью песка также зафиксирован для сосуда раннего типа. Оба этих этапа обычно охватывают первые несколько первых лет после начала процесса смешения

Третий этап смешения проявляется в навыках обработки поверхности сосудов. Смешанные навыки на ступени обработки поверхности зафиксированы для большинства сфероконусов - заглаживание на гончарном круге и лощение. Четвёртый этап проявляется в смешении традиций формообразования сосудов. Для всех сосудов зафиксированы признаки формообразования сосудов с приме- нением гончарного круга (РФК от 4 до 6) и для большинства зафиксировано использование формы-модели для формообразования начина. Эти два этапа обычно охватывают период жизни одного-двух поколений гончаров. Этапы пять и шесть связаны со смешением традиций на ступенях изготовления начина и полого тела. Сочетание навыков в конструировании практически всех сфероконусов имеет смешанный характер - начин изготовлен способом скульптурной лепки, а полое тело - вытягиванием из жгута. Несмешанные навыки в конструировании зафиксированы для сосудов и раннего и позднего типов - начин и полое тело изготовлены способами скульптурной лепки. Процесс смешения технологических традиций пятого и шестого этапов проходит в течение жизни нескольких поколений гончаров.

Таким образом, общий комплекс технологических навыков изготовления сфероконусов Болгарского городища можно охарактеризовать следующим образом. Приспособительные навыки (отбор ИПС и подготовка ФМ) отличаются однородностью и несмешанностью. Вероятно, даже сложные рецепты с минеральной и органической примесями появились в системе навыков гончаров Болгра 
Таблица 9. Распределение сфероконусов разных типов по условным районам отбора ИПС

Table 9. Distribution of the various types of spherical cones in terms of the conditional IPS

sampling areas

\begin{tabular}{|c|c|c|c|c|c|}
\hline \multirow{2}{*}{ РАЙОН } & \multicolumn{5}{|c|}{ ТИП } \\
\hline & I-II & III & IV & ИМП & $?$ \\
\hline$P 1$ & СФ-7 & СФ-14 & & & \\
\hline$P 2$ & СФ-17 СФ-12 & СФ-4, СФ-11, СФ-16 & СФ-6 & & \\
\hline$P 3$ & & CФ-1 & & & \\
\hline$P 4$ & & СФ-15 & & & \\
\hline$P 5$ & & СФ-3 & & & \\
\hline$P 6$ & & & & & СФ-26 \\
\hline$P 7$ & & СФ-2 & & & \\
\hline$P 8$ & СФ-20 & & & & \\
\hline$P 9$ & СФ-8, СФ-9, СФ-25 & & & & \\
\hline$P 10$ & & СФ-18, СФ-21 & & & СФ-23, СФ-24 \\
\hline P 11 & СФ-5 & & & & \\
\hline$P 12$ & & & & СФ-19 & \\
\hline$P 13$ & СФ-22 & & & & \\
\hline
\end{tabular}

уже в готовом виде. В представлениях гончаров о глине как сырье для изготовления сфероконусов можно выделить два направления. Во-первых, глина является основным сырьём - формовочные массы с неглинистыми компонентами в составе с незначительной или средней их концентрацией. В таком случае производство сфероконусов относится к археогончарному уровню производства керамики. Во-вторых, глина является единственным сырьём для изготовления сфероконусов, специально введённых примесей не зафиксировано. В таком случае уровень производства можно охарактеризовать как неогончарный. Субстратные навыки, наоборот, характеризуются неоднородностью и смешанностью. Такие представления об ИПС, уровень РФК от 4 до 6, а также обжиг сосудов с использованием горнов подтверждают высказанное ранее мнение исследователей о ремесленном производстве сфероконусов в Болгаре, ориентированном на сбыт продукции на рынке.

Анализ совокупности результатов техникотехнологического анализа сфероконических сосудов позволил выделить несколько технологических групп сфероконусов, которые могут быть соотнесены с определённой традицией в производстве этой специфической категории керамических изделий. В основе выделения группы - способ конструирования сосуда. Удалось выявить 6 технологических групп сфероконусов, которые позволяют выявить отличия в технологии изготовления сосудов разных типов (табл. 10). Сосуды типа I-II были изготовлены гончарами, система навыков которых имела следующие черты: в качестве ИПС использовались только слабозапесоченные глины, характеристики которых соответствуют условным районам Р1, Р2, Р6, Р8, Р9, Р13; зафиксировано два массовых рецепта ФМ - глина без добавления примесей и глина с примесью органики, единично зафиксированы рецепты с примесью песка; в конструировании начина выделено две основные традиции - изготовление способом лоскутного налепа по ёмкостно-донной программе и использование формы-ёмкости или по донно-ёмкостной программе с использованием формы-ёмкости лоскутным или спирально-жгутовым налепом; полое тело изготовлено способом вытягивания; уровень РФК 4-6. В изготовлении сосудов типа III выявлены более разнообразные технологические навыки. В качестве исходного пластичного сырья использовались не только слабозапесоченные глины и смеси на их основе, но и запесоченные глины, соответствующие условным районам P1-P5, P7, P10. Зафиксировано те же два массовых рецепта, что выделены для сфероконусов раннего типа. В навыках конструирования начина зафиксировано несколько способов: один из способов характерен также и для сфероконусов раннего типа (ТГ 2); один из способов связан с изготовлением начина по Д-Ё программе с использованием Ф-О (ТГ 4); также зафиксирован способ 
1

a

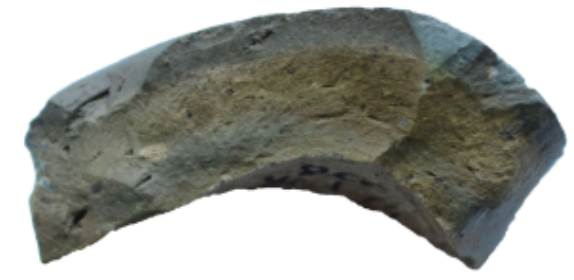

2
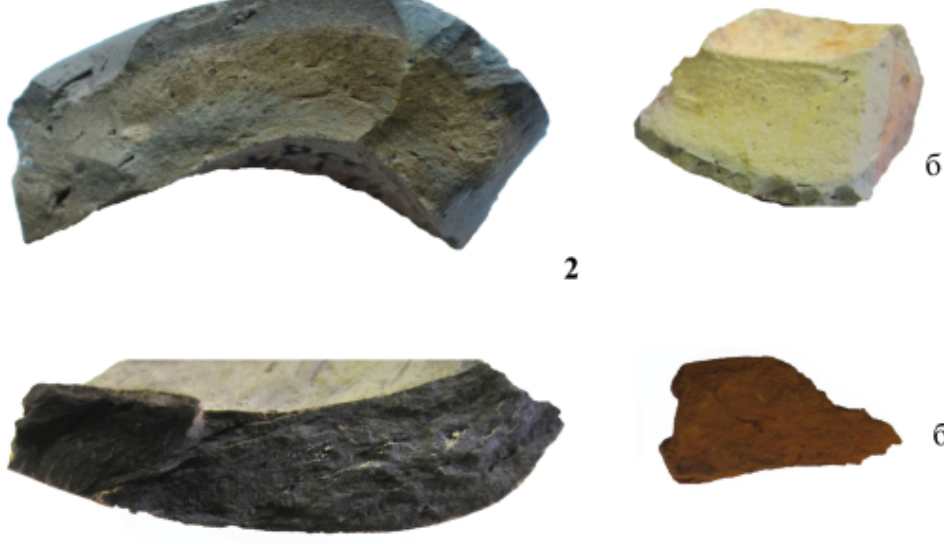

3

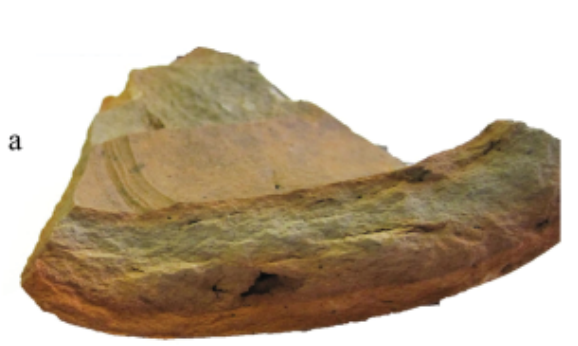

Рис. 11. Цветовые характеристики изломов сфероконусов (а - до вторичного обжига; б - после вторичного обжига при $900{ }^{\circ} \mathrm{C}$ ): 1 - излом сосуда импортного производства (СФ-19); 2 - излом сосуда, обожённого в режиме восстановительной газовой среды (СФ-6); 3 - излом сосуда, обожённого в режиме окислительной газовой среды (СФ-15).

Fig. 11. Color characteristics of spherical cone fractures (a - before secondary firing; 6 - after secondary firing at $900{ }^{\circ} \mathrm{C}$ ): 1 - fracture of a vessel of foreign manufacture (SF-19); 2 - fracture of a vessel burnt in a reducing gas environment (SF-6); 3 - fracture of a vessel burnt in an oxidizing gas environment (SF-15).

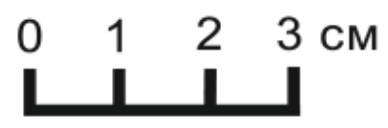

изготовления начина без формы-модели по Ё-Д программе (ТГ 5). Полое тело изготовлено либо способом вытягивания или лоскутным налепом.

В результате определения потенциальной сырьевой базы было получено соответствие одного сфероконуса позднего типа и одного из образцов глинистого сырья. Фрагмент данного изделия представляет собой верхнюю часть от сосуда, изготовленного из сильнозапесоченной глины с примесью выжимки из навоза, полое тело изготовлено способом вытягивания (сфероконус с шифром СФ-3). Образец глины (БГ 14-4) был отобран к западу от городища вблизи болгарского поселения в урочище Ага-Базар (рис. 12). На этом поселении А.П. Смирновым был исследован горн для обжига керамики, постройку и эксплуатацию которого соотнёс с концом XIII - началом XIV вв. (Смирнов, 1962, с. 90-92) Близкие по конструкции горны были изучены О.С. Хованской в пойме р. Меленки (Хованская, 1954, с. 355). Нельзя уверенно утверждать, что данный сосуд позднего типа был изготовлен в мастерских подгорной части или поселения Ага-Базар. На данный момент мы не располагаем сведениями о типологическом составе сфероконусов, обнаруженных при изучении гончарных производственных комплексов в пойме р. Меленки. Сосуды позднего типа производились в одной из мастерских в районе Голландского озера, изученной в 2016 г. (Бочаров, 2018, с. 264, рис. 8).

Сосуды типа I-II (ранний тип) относятся к числу сфероконусов так называемого «классического типа». Традиции производства этого типа сформировались в Средней Азии в IX-XI вв. и просуществовали вплоть до XV в. 3.С. Галиева выделяет комплекс сосудов этого типа с территории Поволжья и в качестве отличительных черт отмечает красно-коричневый цвет черепка (Галиева, 2014, с. 78, 82). Этот тип сосудов преобладает в материалах Болгара и более характерен для раннезолотоордынских комплексов, но встречается и в напластованиях, отложившихся в домонгольское время. Сфероконусы типа III (поздний тип) с конусовидной формой тулова наиболее характерны для материалов, полученных из позднезолотоордынских отложений (Хлебникова, 1988, с. 92-93). Сфероконусы этого типа выявлены в материалах золотоордынских 


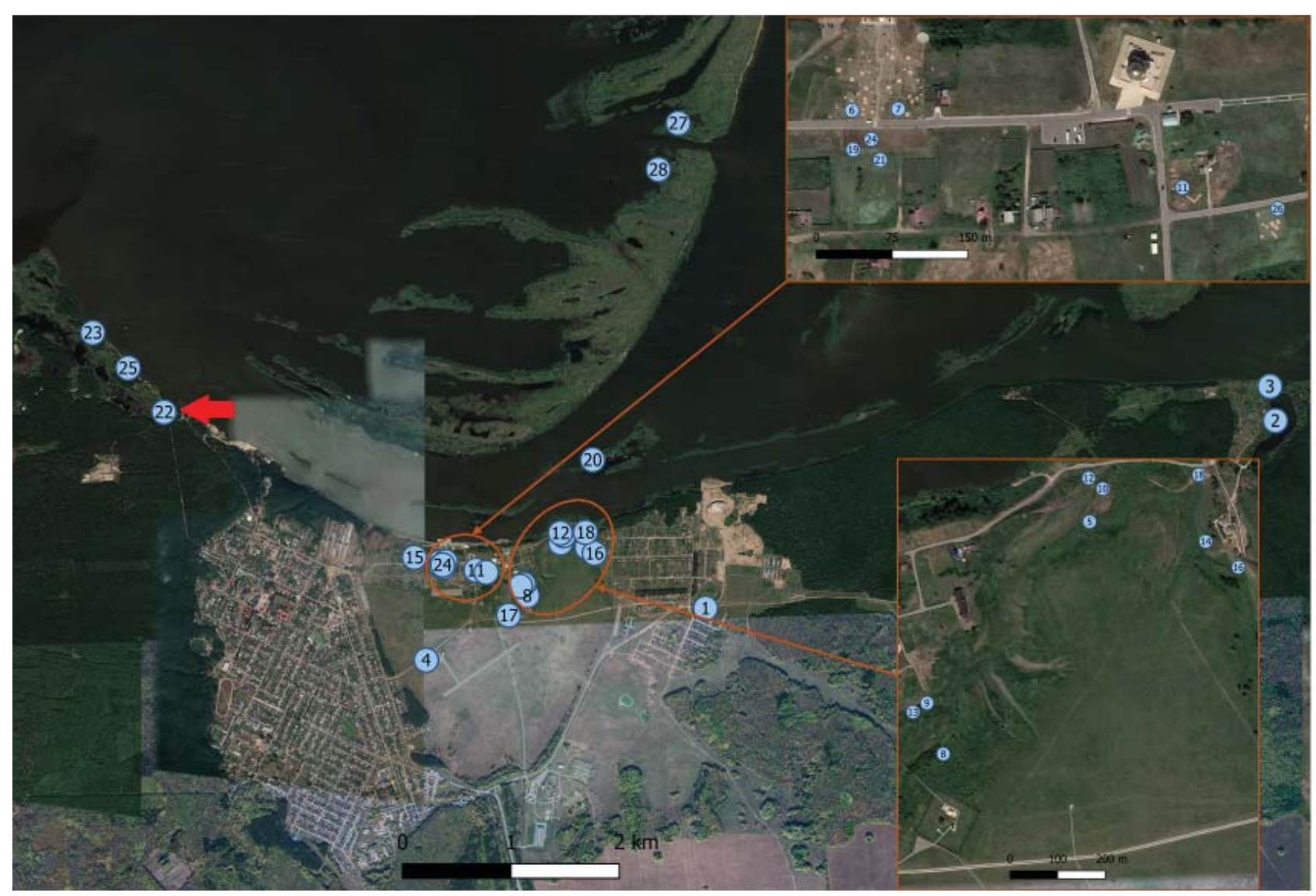

Рис. 12. Карта отбора образцов глинистого сырья: $\mathbf{1}$ - шифр образца г 7-1; 2 - шифр образца г 7-2; 3 - шифр образца г 7-3; 4 - шифр образца БГ 1-13; 5 - шифр образца БГ 2-13; 6 - шифр образца БГ 9-13; 7 - шифр образца БГ 8-13; 8 - шифр образца БГ 4-13; 9 - шифр образца БГ 5-13; 10 - шифр образца БГ 6-13; 11 - шифр образца БГ 10-13; 12 - шифр образца БГ 3-13; 13 - шифр образца БГ 7-13; 14 - шифр образца БГ 11-13;

15 - шифр образца БГ 12-13; 16 - шифр образца БГ 13-13; 17 - шифр образца БГ 14-13; 18 - шифр образца БГ 15-13; 19 - шифр образца БГ14-1; 20 - шифр образца БГ14-2; 21 шифр образца БГ 14-3; 22 - шифр образца БГ 14-4; 23 - шифр образца БГ 14-5; 24 - шифр образца БГ 14-6; 25 - шифр образца БГ 14-7; 26 - шифр образца БГ 14-8; 27 - шифр образца БГ 14-9; 28 - шифр образца БГ 14-10.

Fig. 12. Map of clay raw material sampling: $\mathbf{1}$ - g 7-1 sample code; $\mathbf{2}$ - g 7-2 sample code; $\mathbf{3}-\mathrm{g}$ 7-3 sample code; $\mathbf{4}$ - BG 1-13 sample code; 5 - BG 2-13 sample code; 6 - BG 9-13 sample code; 7 - BG 8-13 sample code; 8 - BG 4-13 sample code; 9 - BG 5-13 sample code; 10 - BG 6-13 sample code; 11 - BG 10-13 sample code; 12 - BG 3-13 sample code; 13 - BG 7-13 sample code; 14 - BG 11-13 sample code; 15 - BG 12-13 sample code; 16 - BG 13-13 sample code; 17 - BG 14-13 sample code; 18 - BG 15-13 sample code; 19 - BG 14-1 sample code; 20 - BG 14-2 sample code; 21 - BG 14-3 sample code; 22 - BG 14-4 sample code; 23 - BG 14-5 sample code; 24- BG 14-6 sample code; 25 - BG 14-7 sample code; 26 - BG 14-8 sample code; 27 - BG 14-9 sample code; 28 - BG 14-10 sample code.

памятников Среднего и Нижнего Поволжья и домонгольского Сувара (Нуретдинова, 2016, с. 15; Нуретдинова, Беляев, 2015, с. 304).

K сожалению, фрагментированность сфероконуса импортного происхождения не позволяет составить подробного представления о форме этого сосуда и найти для него конкретные аналогии. Извлечение его из переотложенных напластований культурного слоя XIX-XX вв. не позволяет также сделать обоснованных выводов о хронологии бытования этого сфероконуса в Болгаре. Отличается от общей массы сосуд с округлой формой дна и обжигом в восстановительной газовой среде. ИПС и ФМ зафиксированные для этого сосуда наиболее характерны для сосудов типа III, а способ конструирования начина - для сосудов типа I-II. Хотя качественные характеристики сырья соответствуют условному району отбора сырья Р2, к которому относятся типы сосудов местного производства. Производство сфероконусов такого типа в Болгаре если и имело место, то было эпизодическим в форме подражания импортным сосудам из Средней Азии.

В этой связи важно остановиться на проблеме типологического состава сфероконусов импортного производства в материалах 
памятников Среднего Поволжья. Традиционно исследователи к сфероконусам импортного происхождения относят сосуды серого и желтовато-серого цвета с плотным черепком, а сосуды желтого, коричневого или красного цветов с более хрупким черепком - к продукции местного производства. В домонгольский период (по материалам Биляра и Сувара) сфероконусы импортного производства преобладали, а в золотоордынское время (по материалам Болгара) наоборот преобладали сосуды местного производства (Халиков, 1986, с. 75-76; Хлебникова, 1988, с. 93; Нуретдинова, 2016, с. 4-5). В результате технологического анализа внимание привлёк фрагмент горла сфероконуса, соответствующего по форме сосудам типа I-II из напластований позднезолотоордынского времени (рис. 4: 2). В составе рецепта ФМ зафиксирована примесь мелкой фракции дресвы в средней концентрации (рис. 7: 1-2). Сложно выяснить происхождение традиции введения дресвы в ФМ сфероконусов, потому что данная традиция не характерна для ремесленного производства керамики Болгара ни в домонгольское ни в золотоордынское время. Примесь дресвы характерна для ФМ «древнерусской» керамики (группа
XIV в соответствие с классификацией T.A. Хлебниковой), бытовавшей в Болгаре в период со второй половины XI до начала XV вв. (Хлебникова, 1988, с. 32, 51; Васильева, 1988, c. 122). Навыки изготовления посуды данной группы сильно отличаются от тех, которыми обладали гончары-ремесленники, изготовлявшие сфероконусы в Болгаре, да и среди ассортимента посуды XIV группы сфероконусы не выделены. Если считать данный сфероконус с примесью дресвы в ФМ результатом смешения технологических навыков двух гончарных систем, то керамика с примесью дресвы должна быть зафиксирована среди других категорий ассортимента «общеболгарской» посуды. По результатам технологического исследования керамики Болгара такой традиции в ремесленном гончарстве зафиксировано не было (Васильева, 1988, с. 103-148). Перечисленные обстоятельства позволяют предположить импортное происхождение данного сфероконуса. Полученные наблюдения позволяют говорить о том, что к сфероконусам импортного происхождения нельзя однозначно относить только сосуды серого или желтого цвета с плотной фактурой черепка. Эта проблема нуждается в отдельном изучении.

Таблица 10. Технологические группы (ТГ) сфероконусов ${ }^{1}$

Table 10. Technological groups (TG) of spherical cones

\begin{tabular}{|c|c|c|c|c|c|c|c|c|}
\hline TГ & ТИП & РФК & ИПС & $\mathbf{P}$ & $\Phi \mathbf{\Phi}$ & НАЧИН & ПОЛОЕ ТЕЛО & OП \\
\hline 1 & I-II & 6 & $\Gamma \mathrm{I}$ & P9 & $\Gamma \mathrm{I}$ & $\begin{array}{c}\text { лоскутный налеп, Ё-Д } \\
\text { программа, использование } \\
\text { Ф-Ё. }\end{array}$ & вытягивание & $\begin{array}{c}\text { заглаживание, } \\
\text { выбивание }\end{array}$ \\
\hline \multirow[t]{2}{*}{2} & I-II & 6 & $\Gamma \mathrm{I}$ & P6, P9 & $\Gamma \mathrm{I}+\mathrm{B}$ & \multirow[t]{2}{*}{$\begin{array}{c}\text { спирально-жгутовой } \\
\text { налеп, Д-Ё программа, } \\
\text { использование Ф-Ё. }\end{array}$} & \multirow[t]{2}{*}{ вытягивание } & $\begin{array}{c}\text { заглаживание, } \\
\text { обстругивание, } \\
\text { лощение }\end{array}$ \\
\hline & III & 6 & $\Gamma \mathrm{I}$ & P3 & ГI+OP & & & заглаживание \\
\hline \multirow{2}{*}{3} & I-II & 6 & $\Gamma \mathrm{I}$ & \multirow{2}{*}{ P2 } & $\Gamma \mathrm{I}+\mathrm{OP}$ & \multirow{2}{*}{$\begin{array}{c}\text { лоскутный налеп, Д-Ё } \\
\text { программа, использование } \\
\text { Ф-Ё. }\end{array}$} & \multirow{2}{*}{$\begin{array}{c}\text { вытягивание, } \\
\text { лоскутный } \\
\text { налеп }\end{array}$} & $\begin{array}{c}\text { заглаживание, } \\
\text { лощение }\end{array}$ \\
\hline & IV & 6 & $\Gamma \mathrm{II}$ & & ГII+B & & & $\begin{array}{c}\text { заглаживание, } \\
\text { лощение }\end{array}$ \\
\hline 4 & III & 6 & $\Gamma \mathrm{I}$ & P2 & $\Gamma \mathrm{I}+\mathrm{B}$ & $\begin{array}{c}\text { лоскутный налеп, Д-Ё } \\
\text { программа, использование } \\
\text { Ф-О. }\end{array}$ & $?$ & $\begin{array}{c}\text { заглаживание, } \\
\text { обстругивание, } \\
\text { лощение }\end{array}$ \\
\hline 5 & III & 4 & $\Gamma \mathrm{I}$ & P7 & $\Gamma \mathrm{I}+\mathrm{B}$ & $\begin{array}{c}\text { спиралевидный налеп из } \\
\text { узких лент, Ё-Д программа } \\
\text { без использования модели }\end{array}$ & $?$ & заглаживание \\
\hline \multirow{2}{*}{6} & \multirow{2}{*}{ III } & \multirow{2}{*}{$4-5$} & $\Gamma \mathrm{I}$ & $\mathrm{P} 2$ & $\Gamma \mathrm{I}$ & \multirow{2}{*}{$\begin{array}{l}\text { лоскутный спиралевидный } \\
\text { налеп, использование Ф-Ё. }\end{array}$} & \multirow{2}{*}{$\begin{array}{c}\text { лоскутный } \\
\text { спиралевидный } \\
\text { налеп }\end{array}$} & \multirow{2}{*}{$\begin{array}{c}\text { заглаживание, } \\
\text { лощение }\end{array}$} \\
\hline & & & KTI & $\mathrm{P} 10$ & $\mathrm{KTI}+\mathrm{B}$ & & & \\
\hline
\end{tabular}

РФК - уровень развития функций гончарного круга, ИПС - исходное пластичное сырьё, ГІ слабозапесоченная глина, КТІ - слабозапесоченная смесь глин, ФМ - формовочная масса, В - выжимка из навоза, ОР - органический раствор, Д-ё - донно-ёмкостная программа, ̈̈-Д - ёмкостно-донная программа, ОП - обработка поверхности. 


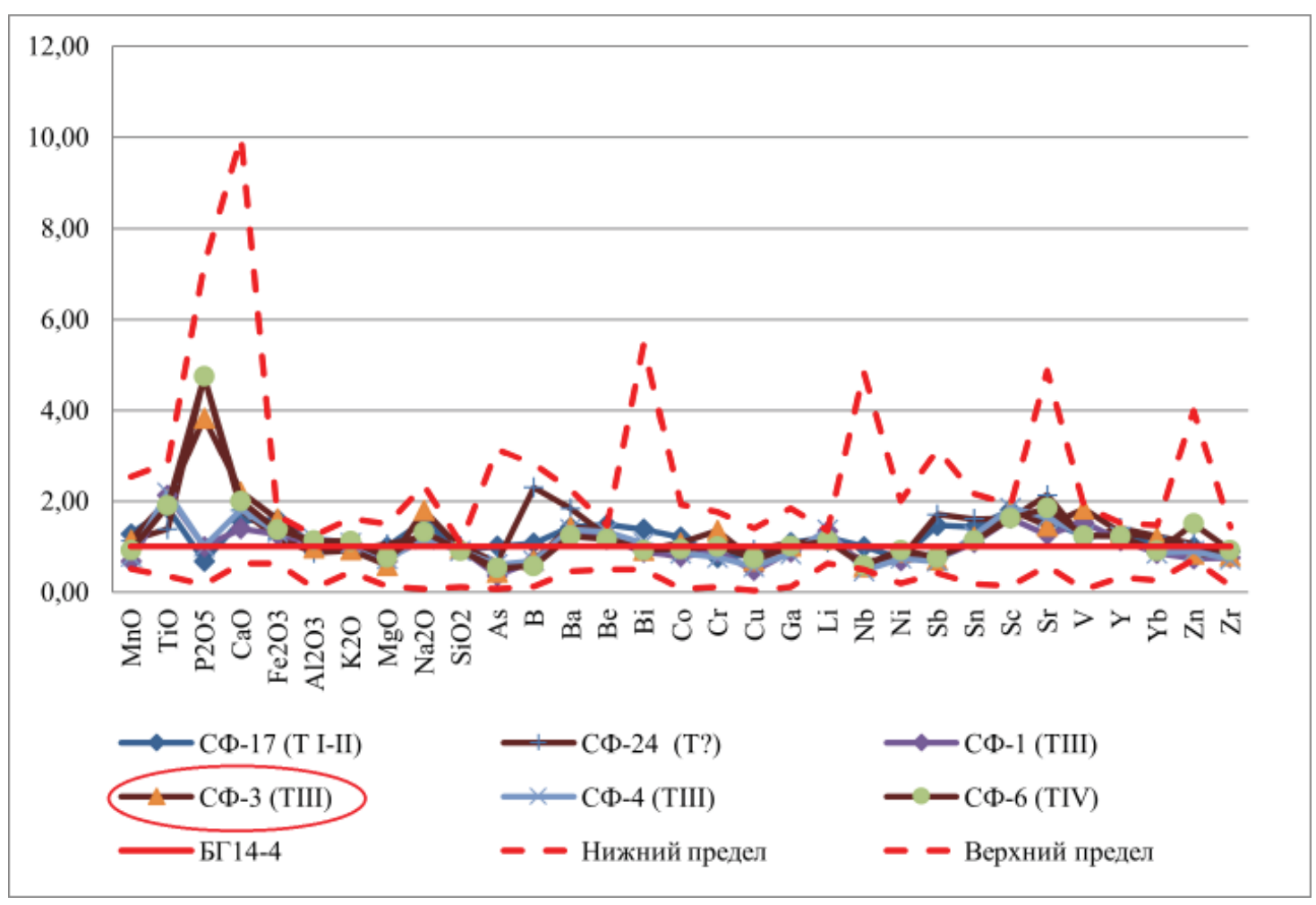

Рис. 13. График соответствия химического состава образца глинистого сырья БГ 14-4 и группы образцов сфероконусов.

Fig. 13. Graph of correspondence of the chemical composition of a clay raw material sample BG 14-4 and a group of spherical cone samples.

Таким образом, обозначенные два типа красноглиняных сфероконусов бытовали в Болгаре не только в золотоордынское, но и в домонгольское время, но достоверных данных о производстве сфероконусов в Болгаре в домонгольское время нет. Учитывая переработанный характер отложений культурного слоя, из которого происходят два фрагмента сфероконусов серого цвета, затруднительно дать их хронологическую характеристику. Бытование сероглиняных сосудов с плотным черепком импортного производства в Болгаре, по аналогии с керамикой Биляра, Т.А. Хлебникова связывала с домонгольским временем (Хлебникова, 1988, с. 97), хотя сфероконусы серого цвета встречаются и среди находок из более поздних отложений золотоордынского времени (Дэвлет и др., 2017, с. 58). Примерная аналогия сосуду с яйцевидной формой тулова и уплощенным дном была также найдена в материалах Биляра - тип IV (Халиков, 1986, c. 81). Материалы данного памятника имеют сугубо домонгольскую датировку. Изученный нами сосуд отличается от тех, что описал A.X. Халиков, фактурой черепка и вероятно технологией производства, что, безусловно, не позволяет провести прямые аналогии с материалами домонгольского времени.

Выводы. Результаты проведённого исследования сфероконических сосудов позволили значительно пополнить информацию о традициях производства сфероконусов в золотоордынском Болгаре. Можно предположить, что производством сосудов раннего типа (I-II) началось в мастерских подгорной части Болгара, датируемые О.С. Хованской первой четвертью XIV в. (Хованская, 1954, с. 352) Производство отличалось высоким техническим уровнем - использование гончарного круга не только для заглаживания и формообразования, но и для частичного вытягивания верхних частей сосудов. В середине XIV в. в подгорной части функционировала другая мастерская, отличавшаяся от этой другой конструкцией горна и низким техническим уровнем производства посуды (Хованская, 1954, с. 354). В 30-60 гг. XIV в. функционировал производственный комплекс в районе Голландского озера (Хованская, 1954, с. 340-368; Полякова, 1980, с. 23; Бочаров, 2018, c. 267). Вероятно, здесь изготовлялись сосуды позднего типа (III). Появление этого типа 
сосудов связано с притоком гончаров, имеющих также ремесленный уровень изготовления посуды, но обладающие отличающимся комплексом технологических навыков - в качестве исходного пластичного сырья могли использоваться запесоченные глины, изготовление начина и полого тела исключительно способами скульптурной лепки, а гончарный круг использовался только для формообразования и заглаживания. Представленный в данной выборке комплекс сосудов как позднего, так и раннего типа имеет признаки смешанности технологических навыков на ступенях конструирования сосудов. Существование минимум двух культурных групп, занимавшихся изготовлением сфероконусов, подтверждают и результаты работы по выявлению условных районов отбора исходного сырья. Зафиксированы районы отбора только гончарами изготовлявшими сфероконусы раннего или позднего типов. Об их смешанности - районы отбора сырья гончарами, производившими сосуды обоих типов.

Полученные результаты показали перспективность организации подобных комплексных исследований. Для решения вопроса о традициях производства именно сфероконических сосудов в золотоордынском Болгаре необходимо расширение выборки сосудов для изучения как из материалов раскопов по всей площади городища, так и из материалов производственных комплексов

\section{ЛИТЕРАТУРА}

Бадеев Д.Ю. Ремесленные районы золотоордынского Болгара: попытка локализации // Археология Евразийских степей. 2018. №5. С. 81-86.

Баранов В.С. Отчет об археологических охранно-спасательных исследованиях на территории Болгарского городища на раскопе CLIII на месте предстоящего строительства БКТП и котельной речного вокзала в 2011 году. Ч. I-III. Казань, 2016 / НФ МАРТ ИА АН РТ

Баранов В.С. Отчет об археологических охранных исследованиях на участке предстоящего благоустройства территории Речного вокзала объекта культурного наследия федерального значения «Городище «Болгар» - столица Болгарского государства» в Спасском р-не Республики Татарстан в 2012 году (раскоп CLXXXII). Ч. I-V. Казань, 2016 / НФ МАРТ ИА АН РТ.

Баранов B.C. Отчет об археологических охранно-спасательных исследованиях на участке предстоящего благоустройства территории Речного вокзала объекта культурного наследия федерального значения «Городище «Болгар» - столица Болгарского государства в Спасском районе Республики Татарстан в 2012 году. Казань, 2018 / НФ МАРТ ИА АН РТ.

Баранов В.С., Губайдуллин А.М. Отчет. Археологические охранно-спасательные исследования на территории Болгарского городища (р. CLIX) в 2011 году. Т VII. Кн. 1. Казань, 2012a НФ MAPТ ИА АН PT.

Баранов В.С., Губайдуллин А.М. Отчет. Археологические охранно-спасательные исследования на территории Болгарского городища (р. CLVIII) в 2011 году. Т XIII. Кн. 1. Казань, 2012б / НФ МАРТ ИА AH PT.

Бахматова B.Н., Куклина А.А. О связи технологии изготовления общеболгарских керамических сосудов с их функциональным предназначением: характеристика формовочных масс (по материалам исследования Болгарского городища 2011-2012 гг.) // Поволжская археология. 2014. №2(8). С. 230 -255.

Бахматова В.Н., Сивицкий М.В., Ситдиков А.Г., Храмченкова Р.Х. Междисциплинарные исследования сфероконических сосудов золотоордынского Болгара (по материалам раскопа 200, 2014 г.) // Труды III Международного конгресса средневековой археологии евразийских степей «Между Востоком и Западом: движение культур, технологий и империй» / Ред. Н.Н. Крадин, А.Г. Ситдиков. Владивосток: Дальнаука, 2017. С. 34-38.

Бахматова B.Н., Ситдиков А.Г. Районы и места отбора исходного сырья в гончарном производстве Болгара: источники и проблемы идентификации (по материалам аналитических исследований) // Поволжская археология. 2017. № 2(20). С. 255-281.

Бахматова В.Н., Храмченкова Р.Х., Ситдиков А.Г. Исследования керамики и источников глинистого сырья в керамическом производстве Среднего Поволжья XIII - XIV вв. // Поволжская археология. 2017. №4(22). С. 126-146.

Бобринский A.A. Гончарная технология как объект историко-культурного изучения // Актуальные проблемы изучения древнего гончарства / Ред. А.А. Бобринский. Самара: Изд-во Самар. гос. пед. ун-та, 1999. C. 5-110. 

$272 \mathrm{c}$.

Бобринский А.А. Гончарство Восточной Европы. Источники и методы изучения. М.: Наука, 1978.

Бочаров С.Г. Археологические исследования гончарных горнов на Болгарском городище в 2016 году (раскоп CCXVI) // Поволжская археология. 2018. № 2(24). С. 253-269.

Валиев Р.Р. Отчет об археологических охранно-спасательных исследованиях на территории Болгарского городища в Спасском р-не Республики Татарстан на раскопе CLXXXI на месте благоустройства территории речного вокзала в 2012 году. Т. І. часть І. Казань, 2014 / НФ МАРТ ИА АН РТ.

Валиев Р.Р., Бадеев Д.Ю. Результаты археологических исследований на Болгарском городище в 2010 г. (раскоп CLIII) // Археология Евразийских степей. 2018. №5. С. 137-141.

Васильева И.Н. Гончарство Волжской Болгарии в X-XIV вв. Екатеринбург: Наука, 1993. 246 с.

Васильева И.Н. О технологии производства неполивной керамики Болгарского городища / Город Болгар: Очерки ремесленной деятельности / Отв. ред. Г.А. Фёдоров-Давыдов. М: Наука, 1988. С. 103-148.

Галиева 3.С. Типология сфероконических сосудов Средней Азии // РА. 2014. № 1. С. 75-87.

Дэвлет Е. Г., Нуретдинова А.Р., Сивиџкий М.В. Реконструкция возможного использования сфероконуса из Болгара // РА. 2017. № 3. С. 57-70.

Нуретдинова А.P. Сфероконические сосуды Суварского городища. Казань: Изд-во Казан. ун-та, 2016. $52 \mathrm{c}$.

Нуретдинова А.Р., Беляев А.В. Сфероконические сосуды раскопа CLXV Болгарского городища // Поволжская археология. 2015. № 4(14). С. 301-310.

Полякова Г.Ф. Отчет о работе на Болгарском городище в 1980 году. Раскоп LXX / Док. фонд БГИАЗ. Инв. № 66-1. КП-405.

Ситдиков А.Г. Отчет об археологических раскопках в Спасском районе, г. Болгар, на Болгарском городище (Раскоп CCXVI) в 2016 году. Т. I-IV. Казань, 2017 / НФ МАРТ ИА АН РТ.

Ситдиков А.Г. Отчет об археологических охранно-спасательных исследованиях на Болгарском городище (Республика Татарстан), при благоустройстве территории у здания «Речной вокзал с функцией музея» за 2013 г. (р. CLXXXV). Т. 1-5. Казань, 2018 / НФ МАРТ ИА АН РТ.

Смирнов А.П. Керамический горн на болгарском поселении Ага-Базар // Труды Куйбышевской археологической экспедиции. Т. 4 / МИА. № 111 / Отв. ред. А.П. Смирнов. М.: Изд-во Академии наук CCCP, 1962. С. 90-92.

Халиков А.Х. Сфероконические сосуды // Посуда Биляра / Отв. ред. А.Х. Халиков. Казань: КФАН CCCР, 1986. С. 72-83.

Хлебникова T.A. История археологического изучения Болгарского городиша. Стратиграфия. Топография / Город Болгар: Очерки истории и культуры / Отв. ред. Г.А. Фёдоров-Давыдов. М.: Наука, 1987. C. $32-88$.

Хлебникова Т.А. Неполивная керамика Болгара // Город Болгар: Очерки ремесленной деятельности / Отв. ред. Г.А. Фёдоров-Давыдов. М.: Наука, 1988. С. 8-102.

Хованская О.С. Гончарное дело города Болгара // Труды Куйбышевской археологической экспедиции. Т. I / МИА. № 42 / Отв. ред. А.П. Смирнов. М.: Изд-во АН СССР, 1954. С. 340-368.

Храмченкова Р.X. Химический состав глин как индикатор сырьевого // Поволжская археология. 2014. №2 (8). C. 176-204.

Храмченкова Р.Х., Бахматова В.Н., Сивицкий М.В. Археометрическое исследование сфероконических сосудов из раскопа СС Болгарского городища // Археология Евразийских степей. 2018. №5. С. 241-242.

Цетлин Ю.Б. Древняя керамика. Теория и методы историко-культурного подхода. М.: ИА РАН, 2012. $384 \mathrm{c}$.

\section{Информация об авторах:}

Бахматова Вера Николаевна, научный сотрудник, Институт археологии им. А.Х. Халикова АН РТ (г. Казань, Россия); lyna-87@yandex.ru

Сивицкий Максим Владимирович, научный сотрудник, Институт археологии им. А.Х. Халикова AН РТ (г. Казань, Россия); m1213@mail.ru

Ситдиков Айрат Габитович, чл.-корр АН РТ, доктор исторических наук, директор, Институт археологии им. А.Х. Халикова АН РТ (г. Казань, Россия); sitdikov_a@mail.ru 


\section{REFERENCES}

Badeev, D. Yu. 2018. In Arkheologiia Evraziiskikh stepei (Archaeology of Eurasian Steppes) 5, 81-86 (in Russian).

Baranov, V. S. 2016. Otchet ob arkheologicheskikh okhranno-spasatel'nykh issledovaniiakh na territorii Bolgarskogo gorodishcha na raskope CLIII na meste predstojashhego stroitel'stva BKTP i kotel'noi rechnogo vokzala v 2011 godu (Report on Archaeological Rescue Studies in the Territory of the Bolgar Fortified Settlement at Excavation CLIII at the Future Construction Site of a CCTS and Boiler House of the River Station in 2011). Parts. 1-3. Kazan. Scientific Fund of the Museum of Archaeology of the Republic of Tatarstan, Khalikov Institute for Archaeology, Tatarstan Academy of Sciences (in Russian).

Baranov, V. S. 2016.Otchet ob arkheologicheskikh okhrannykh issledovaniiakh na uchastke predstojashchego blagoustroistva territorii Rechnogo vokzala obekta kul'turnogo nasledija federal'nogo znacheniia «Gorodishche «Bolgar» - stolitsa Bolgarskogo gosudarstva» v Spasskom r-ne Respubliki Tatarstan v 2012 godu (raskop CLXXXII). (Report on Archaeological Rescue Studies at the Future Improvement Site in the Territory of the River Station of the "Bolgar Fortified Settlement Cultural Heritage Site of Federal Significance - the Capital of Bolgar State" in the Spassky District of the Republic of Tatarstan in 2012 (Excavation CLXXXII).). Paarts. 1-5. Kazan. Scientific Fund of the Museum of Archaeology of the Republic of Tatarstan, Khalikov Institute for Archaeology, Tatarstan Academy of Sciences (in Russian).

Baranov, V. S. 2018. Otchet ob arkheologicheskikh okhranno-spasatel'nykh issledovaniiakh na uchastke predstoiashhego blagoustroistva territorii Rechnogo vokzala obekta kul'turnogo naslediia federal'nogo znacheniia «Gorodishche «Bolgar» - stolitsa Bolgarskogo gosudarstva v Spasskom raione Respubliki Tatarstan v 2012 godu (Report on Archaeological Security and Rescue Studies at the Future Improvement Site in the Territory of the River Station of the "Bolgar" Settlement Cultural Heritage Site of Federal Significance - the Capital of Bolgar State" in the Spassky District of the Republic of Tatarstan in 2012). Kazan. Scientific Fund of the Museum of Archaeology of the Republic of Tatarstan, Khalikov Institute for Archaeology, Tatarstan Academy of Sciences (in Russian).

Baranov, V. S., Gubaidullin, A. M. 2012a. Otchet. Arkheologicheskie okhranno-spasatel'nye issledovaniia na territorii Bolgarskogo gorodishcha (r. CLIX) v 2011 godu.) (Report. Archaeological Security and Rescue Studies in the Territory of Bolgar Settlement (Excavation CLIX) in 2011.). Vol. 7. Book 1. Kazan. Scientific Fund of the Museum of Archaeology of the Republic of Tatarstan, Khalikov Institute for Archaeology, Tatarstan Academy of Sciences (in Russian).

Baranov, V. S., Gubaidullin, A. M. 2012b. Otchet. Arkheologicheskie okhranno-spasatel'nye issledovaniia na territorii Bolgarskogo gorodishcha (r. CLIX) v 2011 godu.) (Report. Archaeological Rescue Studies in the Territory of Bolgar Fortified Settlement (Excavation CLIX) in 2011.). Vol. 13. Book 1. Kazan. Scientific Fund of the Museum of Archaeology of the Republic of Tatarstan, Khalikov Institute for Archaeology, Tatarstan Academy of Sciences (in Russian).

Bakhmatova, V. N., Kuklina, A. A. 2014. In Povolzhskaya arkheologiya (Volga River Region Archaeology) 8 (2), 230-255 (in Russian).

Bakhmatova, V. N., Sivitsky, M. M., Sitdikov, A. G., Kramchenkova, R. Kh. 2017. In Kradin, N. N., Sitdikov, A. G. (eds.). Trudy III Mezhdunarodnogo kongressa srednevekovoi arkheologii evraziiskikh stepei "Mezhdu Vostokom i Zapadnom: dvizhenie kul'tur, tekhnologii i imperii" (Preceedings of 3rd International Congress on Medieval Archaeology of Eurasian Steppes "Between the East and the West: Movements of Cultures, Technologies and Empires"). Vladivostok: "Dal'nauka" Publ., 34-38 (in Russian).

Bakhmatova, V. N., Sitdikov, A. G. 2017. In Povolzhskaya arkheologiya (Volga River Region Archaeology) 20 (2), 255-281 (in Russian).

Bakhmatova, V. N., Khramchenkova, R. Kh., Sitdikov, A. G. 2017. In Povolzhskaya arkheologiya (Volga River Region Archaeology) 22 (4), 126-146 (in Russian).

Bobrinsky, A. A. 1999. In Bobrinsky, A. A. (ed.). Aktual'nye problemy izucheniia drevnego goncharstva (kollektivnaia monografiia) (Current Issues of Ancient Pottery Study: Collective Monograph). Samara: Samara State Pedagogical University, 5-109 (in Russian).

Bobrinsky, A. A. 1978. Goncharstvo Vostochnoi Evropy. Istochniki i metody izucheniia (East European Pottery. Sources and Research Methods). Moscow: "Nauka" Publ. (in Russian).

Bocharov, S. G. 2018. In Povolzhskaya arkheologiya (Volga River Region Archaeology) 24 (2), 253-269 (in Russian).

Valiev, R. R. 2014. Otchet ob arkheologicheskikh okhranno-spasatel'nykh issledovaniiakh na territorii Bolgarskogo gorodishcha $v$ Spasskom r-ne Respubliki Tatarstan na raskope CLXXXI na meste blagoustroistva territorii rechnogo vokzala v 2012 godu (Report on Archaeological Rescue Studies on in the territory of Bolgar Fortified Settlement in the Spassky District of the Republic of Tatarstan at Excavation CLXXXI in the River 
Station Improvement Territory in 2012). Vol. 1. Part. 1. Kazan. Scientific Fund of the Museum of Archaeology of the Republic of Tatarstan, Khalikov Institute for Archaeology, Tatarstan Academy of Sciences (in Russian).

Valiev, R. R., Badeev, D. Yu. 2018. In Arkheologiia Evraziiskikh stepei (Archaeology of Eurasian Steppes) 5, 137-141 (in Russian).

Vasil'eva, I. N. 1993. Goncharstvo Volzhskoi Bolgarii v X-XIV vv. (Pottery of Volga Bolgaria in the 10 ${ }^{\text {th }}$ $14^{\text {th }}$ cc.). Ekaterinburg: "Nauka" Publ. (in Russian).

Vasil'eva, I. N. 1988. In Fedorov-Davydov, G. A. (ed.). Gorod Bolgar. Ocherki remeslennoi deiatel'nosti (City of Bolgar. Essays on Handicrafts). Moscow: "Nauka" Publ. (in Russian).

Galieva, Z. S. 2014. In Rossiiskaia Arkheologiia (Russian Archaeology) (1), 75-70 (in Russian).

Devlet, E. G., Nuretdinova, A. R., Sivitsky, M. V. In Rossiiskaia Arkheologiia (Russian Archaeology) (3), 57-70 (in Russian).

Nuretdinova, A. R. 2016. Sferokonicheskie sosudy Suvarskogo gorodishcha (Sphero-Conical Vessels from Suvar Fortified Settlement). Kazan: Kazan Federal University (in Russian).

Nuretdinova, A. R., Belyaev, A. V. 2015. In Povolzhskaya arkheologiya (Volga River Region Archaeology) 14 (4), 301-310 (in Russian).

Poliakova, G. F. Otchet o rabote v Bolgarakh v 1980 godu (raskop LXX) (Report on the fieldworks in Bolgar in 1980 (Excavation Area LXX)). Documental Fund of the Bolgar State Historical and Architectural Reserve, Inv. 66-1`. KP-405; (in Russian).

Sitdikov, A. G. 2017. Otchet ob arkheologicheskikh raskopkakh v Spasskom raione, g. Bolgar, na Bolgarskom gorodishche (Raskop CCXVI) v 2016 godu (Report on Archaeological Excavations in the Spassky District, Bolgar Town, at Bolgar Settlement (Excavation CCXVI) in 2016). Vol. 1-4. Kazan. Scientific Fund of the Museum of Archaeology of the Republic of Tatarstan, Khalikov Institute for Archaeology, Tatarstan Academy of Sciences (in Russian).

Sitdikov, A. G. 2018.Otchet ob arkheologicheskikh okhranno-spasatel'nykh issledovaniiakh na Bolgarskom gorodishche (Respublika Tatarstan), pri blagoustrojstve territorii u zdaniia «Rechnoi vokzal s funkciei muzeia» za 2013 g. (r. CLXXXV). (Report on Archaeological Rescue Studies at Bolgar Fortified Settlement (the Republic of Tatarstan) during the Improvement of the Territory near the building of the "River Station with Museum Functions" for 2013 (Excavation CLXXXV)). Vol 1-5. Kazan. Scientific Fund of the Museum of Archaeology of the Republic of Tatarstan, Khalikov Institute for Archaeology, Tatarstan Academy of Sciences (in Russian).

Smirnov, A. P. 1962. In Smirnov, A. P. (ed.). Trudy Kuybyshevskoi arkheologicheskoi ekspeditsii (Proceedings of the Kuybyshev Archaeological Expedition) 4. Materialy i issledovaniia po arkheologii SSSR (Materials and Studies in the USSR Archaeology) 111. Moscow: Academy of Sciences of the USSR, 90-92 (in Russian).

Khalikov, A. Kh.1986. In Khalikov, A. Kh. (ed.). Posuda Biliara (Dishware of Bilyar). Kazan: Kazan Branch of the USSR Academy of Sciences, 72-83 (in Russian).

Khlebnikova, T. A. 1987. In Fedorov-Davydov, G. A. (ed.). Gorod Bolgar. Ocherki istorii i kul'tury (City of Bolgar. Essays on History and Culture). Moscow: "Nauka" Publ., 8-102 (in Russian).

Khlebnikova, T. A. 1988. In Fedorov-Davydov, G. A. (ed.). Gorod Bolgar. Ocherki remeslennoi deiatel'nosti (City of Bolgar. Essays on Handicrafts). Moscow: "Nauka" Publ., 8-102 (in Russian).

Khramchenkova, R. Kh., Bakhmatova, V. N., Sivitskii, M. V. 2018. In Arkheologiia Evraziiskikh stepei (Archaeology of Eurasian Steppes) 5, 241-242 (in Russian).

Khovanskaia, O. S. 1954. In Smirnov, A. P. (ed.). Trudy Kuybyshevskoi arkheologicheskoi ekspeditsii (Proceedings of the Kuybyshev Archaeological Expedition) I. Series: Materialy i issledovaniia po arkheologii SSSR (Materials and Studies in the Archaeology of the USSR) 42. Moscow: Academy of Sciences of the USSR, 356-368 (in Russian)..

Tsetlin, Yu. B. 2012. Drevniaia keramika. Teoriia i metody istoriko-kul'turnogo podkhoda (Ancient Ceramics. The Theory and Methods of Historical and Cultural Approach). Moscow: Institute of Archaeology of the Russian Academy of Sciences (in Russian).

Khramchenkova, R. Kh. 2014. In Povolzhskaya arkheologiya (Volga River Region Archaeology) (2), 176-204 (in Russian).

\section{About the Authors:}

Bakhmatova Vera N., научный сотрудник, Институт археологии им. А.Х. Халикова АН РТ (г. Казань, Россия); lyna-87@yandex.ru

Sivitsky Maksim V. Institute of Archaeology named after A. Kh. Khalikov, Tatarstan Academy of Sciences. Butlerov Str., 30, Kazan, 420012, the Republic of Tatarstan, Russian Federation; m1213@mail.ru 
Sitdikov Airat G. TAS Corresponding Member. Doctor of Historical Sciences. Professor. Kazan (Volga Region) Federal University. Kremlyovskaya St., 18, Kazan, 420000, the Republic of Tatarstan, Russian Federation; Institute of Archaeology named after A. Kh. Khalikov, Tatarstan Academy of Sciences. Butlerov Str., 30, Kazan, 420012, the Republic of Tatarstan, Russian Federation; sitdikov_a@mail.ru

Статья поступила в журнал 01.10.2021 г. Статья принята к публикации 01.12.2021 г. Авторы внесли равноценный вклад в работу. 